\title{
Isolation, Characterization and Bio-Control Activities of Bacillus Subtilis from the Fermented Soybean in Cambodia
}

\author{
Ek Sopheap ${ }^{1}$, Yasuhiro Inatsu ${ }^{2}$, Huon Thavrak ${ }^{3}$ and Buntong Borarin ${ }^{4}$ \\ 1. Faculty of Agro-Industry, Royal University of Agriculture, Phnom Penh 12000-12401, Cambodia \\ 2. Food Hygiene Laboratories, Food Safety Division, National Food Research Institute, Tsukuba, Ibaraki 305-8642, Japan \\ 3. Graduate School, Royal University of Agriculture, Phnom Penh 12000-12401, Cambodia \\ 4. Division of Research and Extension, Royal University of Agriculture, Phnom Penh 12000-12401, Cambodia
}

\begin{abstract}
The objective of this study was to isolate Bacillus subtilis produced Bacteriocin from Khmer traditional fermented soybean to control the growth of pathogenic bacteria from 120 SIENG samples from 9 different local open markets in Phnom Penh, 1 local open market and 2 local producers in Kandal province in Cambodia. 119 out of 120 samples were positive with Bacillus subtilis strains. Fifteen of these isolated strains exhibited antimicrobial activity to Lactobacillus plantarum by agar well diffusion assay and one of them (CeM6-7 strain) exhibited strongest antimicrobial activity. The filtered supernatant of this strain also suppressed the growth of several Gram-positive pathogens (such as Staphylococcus aureus) or lactic acid bacteria in broth. The filtrate could also suppress the growth of L. plantarum inoculated into soymilk. Antimicrobial B. subtilis strain CeM6-7 is thought to be applicable for making a starter culture to produce much safe fermented soybean foods by suppressing the growth of naturally contaminated $B$. cereus or $S$. aureus during production. In addition, the use of this starter culture may contribute to prevent spoilage or quality loss of soybean products caused by the over growth lactic acid bacteria or other Gram-positive bacteria.
\end{abstract}

Key words: $B$. subtilis, fermented soybean, bacteriocin, food poisoning, spoilage bacterial.

\section{Introduction}

Fermented foods are commonly produced in Cambodia and other South-Eastern courtiers since they are cheap, high nutrient values and benefit for health. In Cambodia, soybean is categorized in the fourth main agricultural commodities list which is actively generated yearly income for rural farmers [1] and certain amount of soybean are used for fermented soybean production, commonly called SIENG in Cambodian which famous and healthy foods among other Cambodian's soybean processed products. There are 2 kinds of fermented SIENG in Cambodia, SIENG PRAI (salted Soybean), and SIENG PA-AEM (Soybean which made from salts and sugar). Not only

Corresponding author: Ek Sopheap, M.Eng, Vince Dean and Researcher, research fields: grain quality and food safety. in Cambodia but also Japan, Korea, Taiwan, and China are also produced similar fermented soybean products [2].

Bacillus subtilis is a gram-positive bacterium in genus Bacillus which is naturally found in upper layer of the soil [3]. Bacillus subtilis may present on the soybean seed during cultivation or contaminate in SIENG during process according to Cambodia production context which SIENG is fermented using starter Bacillus subtilis, naturally on soybeans in other Asian countries [4]. Up to date research report that antibacterial substance produced by an isolated Bacillus subtilis strain LFB112 from Chinese herbs, was identified as bacteriocins and effective against both Gram-positive and Gram-negative bacteria involved in domestic animal diseases, including Escherichia coli, Salmonella pullorum, Pseudomonas 
aeruginosa, Pasteurella multocida, Clostridium perfingens, Micrococcus luteus, Streptococcus bovis and Staphylococcus aureus [5]. In recent years, considerable effort has been made to develop food applications for many different bacteriocins using bacteriocinogenic strains [6-9]. Bacteriocins produced by industrially important Bacillus subtilis, which have a history of safe use in food and industry [10]. The bacteriocins produced by these strains are thought to be potent food preservative that are applicable and useful for Cambodian food industry.

However, limited research has been done concerning with bacteriocins produced by Bacillus subtilis compared to LAB species as food preservatives. Hence, the objective of this study was to isolate, characterize and optimize the condition antimicrobial Bacillus subtilis strains from fermented soybeans to control Gram-positive pathogenic bacteria (Bacillus cereus, Staphylococcus aureus, etc.) or spoilage lactic acid bacteria in foods.

\section{Material and Methods}

\subsection{Isolation and Screening Bacteriocin Producing Bacillus Subtilis Strains}

One hundred and twenty fermented soybeans samples were purchased from local market in Cambodia. Each of samples was mixed with 10 times volume of nutrient broth and incubated at $35{ }^{\circ} \mathrm{C}$ for 18 $\mathrm{hr}$. The culture was streaked on nutrient agar plate to isolate typical colonies of B. subtilis. All Bacillus strains that have ability to inhibit the grow of indicators from the previous step were streaked into GSP and Mannitol salt agar plate, incubated at $35{ }^{\circ} \mathrm{C}$ for 24-48 h, and isolated bacteria was identified by gram staining and biochemical tests using catalase/OF test.

Antimicrobial activity against indicator organisms was determined by using a well diffusion assay. There were 3 steps conducted in well diffusion assay. The first and second were used exactly the same testing method. However, either the first or second testing is minor different with the third one specifically on (1) with filtration, and (2) without filtration. One loop of each of the spore suspension of isolated B. subtilis strains was inoculated into $5 \mathrm{~mL}$ of $\mathrm{LB}$ broth and incubated at $35{ }^{\circ} \mathrm{C}$ for $18 \mathrm{~h}$. Filtered culture supernatant was subjected to agar well diffusion assay. Lactobacillus plantarum ATCC 8014 was used for indicating bacteria and B. subtilis, Miyagino strain (used for Natto production) were used for negative control, respectively.

\subsection{Characterize the Bacteriocin Produced by Isolated Strain}

\section{- Incubator temperature and timing treatment:}

The spore culture of bacteriocin produced by $B$. subtilis strain was determined. Transferred to $5 \mathrm{~mL}$ of LB broth of $B$. subtilis strain and kept on incubator shaker at $35{ }^{\circ} \mathrm{C}, 72 \mathrm{~h}$, and then were heated and cooled it down. There were 2 steps conducted in well diffusion assay as following:

$0.5 \mathrm{~mL}$ was transferred into $100 \mathrm{~mL}$ aliquots flasks of sterile composed LB broth. Then, the flasks were incubated in 2 deference incubator shakers. In both were started at 7:00 AM, and 17:00 PM the flasks were incubated at $30{ }^{\circ} \mathrm{C}$ and $35{ }^{\circ} \mathrm{C}$, then take $1 \mathrm{~mL}$ of individual sample respectively at each different timing $6,8,10$, and $12 \mathrm{~h}$, and 12, 14, 16, 18, 20, 22 and $24 \mathrm{~h}$, to transfer into micro-centrifuge tubes.

L. plantarum was inoculated into the mixture (1: 1 volume) of MRS broth contained supplement agar and keep it till become solid and make wells, and then filtered culture supernatant of B. subtilis or Miyagino strain and incubated $24 \mathrm{~h}, 30^{\circ} \mathrm{C}$. Growth of inoculated L. plantarum in this MRS broth was measured and observed length of wells by $\mathrm{mm} / \mathrm{mL}$.

\section{- Soy milk treatment:}

The sensitivity of the bacteriocin to enzymes was checked by using a well diffusion assay. B. subtilis and Miyagino strain for control were inoculated into a $30 \mathrm{~mL}$ of LB broth and placed on the incubator shaker at $30{ }^{\circ} \mathrm{C}$ on $250 \mathrm{rpm}$ for overnight. 
$5 \mathrm{~mL} \mathrm{~L}$. plantum, Levconostoc mesentanides Jen 6129, Micrococcus luceus Spi-flams IFo 13867 and Staphylococcus aureus. IFo 13276 were transferred to MRS and LB broth and incubated at $30{ }^{\circ} \mathrm{C}$ and $35{ }^{\circ} \mathrm{C}$, overnight. After dilution all strains were inoculated shaker from 3,6 and $9 \mathrm{~h}$ at $35^{\circ} \mathrm{C}$ into the mixture (1: 1 volume) of soymilk and filtered culture supernatant of B. subtilis or Miyagino strains.

L. plantum, Lev. mesentanides, M. luceus and S. aureus plates, the MRS broth contained agar purified powder and TSA agar, which aimed at asses viable bacteria count over time used by spiral plate systems, are kept in incubator at $35{ }^{\circ} \mathrm{C}$ for $24 \mathrm{hrs}$. Growth of inoculated all indicator strains in this soymilk was measured by plate counting method and calculated the number of CFU/g or $\mathrm{mL}$ of test sample.

Eventually, to evaluate whether all incubated plates are appropriate for the organism sought, we compared by using inoculating culture supernatant against indicator organism. For this purpose, four kinds of bacterial inoculate were prepared in two groups such as MRS broth and LB broth contains $5 \mathrm{~mL}$ L. plantum, Lev. mesentanides, M. luceus and S. aureus, incubated at $30{ }^{\circ} \mathrm{C}$ and $35^{\circ} \mathrm{C}$. Two groups of bacterial inoculate were inoculated into the mixture (1: 1 volume) of MRS broth. After that make wells, and filtered culture supernatant of B. subtilis or Miyagino strain and incubated $24 \mathrm{~h}$, at $30{ }^{\circ} \mathrm{C}$. Growth of inoculated $L$. plantarum in this MRS broth was measured and observed length of wells by arbitrary unit $/ \mathrm{mL}(\mathrm{AU} / \mathrm{mL})$ was calculated [11].

\subsection{Optimize the Bacteriocin Production of the} Bacillus Subtilis Strain by Cultivating in Different Media and Under Different Growth Condition

The optimize bacteriocin production of the $B$. subtilis strain by cultivating in different media and under different growth condition were determined by using the spore culture and well diffusion assay. $B$. subtilis and Miyagino strain are for control. Each strain was separately inoculated into a $5 \mathrm{~mL}$ of $\mathrm{LB}$ broth and placed in the incubator shaker at $37{ }^{\circ} \mathrm{C}$, 24-72 $\mathrm{h}$, heated and cool down, and then store at $-20{ }^{\circ} \mathrm{C}, 24 \mathrm{~h}$.

Next step, spore culture from two strains was series dilution $\left(10^{2}, 10^{4}\right.$, and $\left.10^{6}\right)$ and then spread on TSA agar plats, incubated at $35{ }^{\circ} \mathrm{C}$ for $24 \mathrm{~h}$. Growth of inoculated all indicator strains in this TSA was measured by plate counting method and calculated the number of CFU/g or $\mathrm{mL}$ of test sample. Following counting colonies, $10^{4}$ dilutions were used spore culture into $30 \mathrm{~mL} \mathrm{LB}$ broth in flasks incubator shaker at $30{ }^{\circ} \mathrm{C}$ for 16,20 and $23 \mathrm{~h}$.

Four kinds of bacterial inoculate were prepared in two groups such as MRS broth and LB broth contains $5 \mathrm{~mL}$ L. plantum, Lev. mesentanides, M. luceus and S.aureus, incubated at $30{ }^{\circ} \mathrm{C}$ and $35{ }^{\circ} \mathrm{C}$. Two groups of bacterial inoculate were inoculated into the mixture (1: 1 volume) of MRS broth contained supplement agar and kept it till become solid. After that make wells, and filtered culture supernatant of B. subtilis and Miyagino strains and incubated $24 \mathrm{~h}$ at $30{ }^{\circ} \mathrm{C}$. Growth of inoculated L. plantarum in this MRS broth was measured and observed length of wells by arbitrary unit/mL (AU/mL) [11].

2.4 Apply the Bacteriocin to Control the Growth of Gram Positive Pathogenic or Spoilage Bacteria in Foods

Bacteriocin to control the growth of Gram positive pathogenic or spoilage bacteria in foods was applied by using a well diffusion assay. There were 2 kinds of Bacillus subtilis strains: (1) B. subtilis (Cambodia) and (2) Miyagino for control (Japan). Each strain were inoculated into a $20 \mathrm{~mL}$ of $\mathrm{LB}$ broth centrifuge tubes and placed on the incubator shaker at $35{ }^{\circ} \mathrm{C}, 16 \mathrm{~h}$. Gram positive group ( $S$. avereus, Listeria, and Lactbacillus) and Lactic acid group (L. plantum, $L$. brevis, and $L b$. lactis) were inoculated separately to $\mathrm{BHI}$ and MRS in incubator shaker at $35{ }^{\circ} \mathrm{C}$ for 18 to $24 \mathrm{~h}$.

Filtered culture supernatant of antimicrobial $B$. 
subtilis or Miyagino strains was mixed with same volume of MRS or BHI broth for lactic acid bacteria (L. plantum, L. brevis, and Lb. lactis) or other Gram-positive bacteria, respectively. Each of the pre-cultures of indicator strains was inoculated into this mixture and cultivated at $35{ }^{\circ} \mathrm{C}$. Change of the optical density at $650 \mathrm{~nm}$ was recorded after shaker measure turbidness at OD $650 \mathrm{~nm}$ and dilute until OD 0.1 by PBS all of strains.

\subsection{Data Processing and Analysis}

The results were analyzed by Excel, AU, ANOVA and OD. In analyzing data, both quantitative and qualitative methods were used, and other appropriate methods such as Preference Ranking and Indexing were also used.

\section{Results and Discussion}

\subsection{Isolating Bacillus Strains from Cambodian Fermented Soybean (SIENG) Samples}

120 raw SIENG were isolated for Bacillus strains. As the result, only a total of 119 samples of Bacillus strains were isolated from 120 raw SIENG. Bacillus subtilis strains are important for seed fermentation because of their enzymatic activities contributing to desirable texture, flavor and $\mathrm{pH}$ development [12]. In general, Bacillus Subtilus is the most dominant bacterium in fermented soybean [13]. And it was resistant to heat which showed growth in $70 \mathrm{~g} \cdot \mathrm{dm}^{-3}$ $\mathrm{NaCl}$, nitrate reductase positive reaction [2]. These isolated among 119 Bacillus strains, there were found only 15 Bacillus strains that had ability to fight against the indicator microorganisms. Furthermore, among 15 samples, only one stain (Bacillus CeM6-7) has shown highest level antimicrobial compound of $L$. plantum at $12 \%$ of $15.00 \mathrm{~mm} / \mathrm{mL}$ total zone activity compared to others. One of the main characteristics shared among Bacillus strains is the ability to produce a wide range of antimicrobial compounds active against bacteria. Even though microbial control exerted by these metabolites was demonstrated in plant environments, few reports focused their attention on how these compounds can interact with food microbiota [14]. The rank based on per $\mathrm{mm} / \mathrm{mL}$ and percentage total area of level antimicrobial compound of $L$. plantum showed the trend of all type Bacillus strains.

\subsection{Identification from Isolated Bacteriocin Producing by Bacillus Subtilis Strains}

From the result of previous step, isolating Bacillus strains, the 15 colonies of Bacillus activities strains were developed to have another four additionally. We therefore obtained 19 purified of Bacillus activities strains finally and they were used in this step.

\subsubsection{Biochemical and Morphological of Bacillus} Strains

Bacillus is a genus of Gram-positive, rod-shaped bacteria and a member of the phylum Firmicutes [15]. The samples were spread plated and streaked on GSP agar plate to get the pure culture and the morphology of the colony is observed. As a result, colonies were found to be circular in shape, white to creamish in colour and measured to be $1-3 \mathrm{~mm}$ in size mostly, and the optimum temperature of Bacillus strains in order to growth was between $30-37{ }^{\circ} \mathrm{C}$ [16], but, a well growth condition is $35^{\circ} \mathrm{C}$.

The result revealed that in aerobe production Bacillus strains were growth all strains. In opposite, in anaerobe production, there were only four Bacillus strains grown and had taken a very longer time for growing but stay for only a short life compared to aerobe production because of Bacillus species including $B$. subtilis can be obligated in both condition aerobes (mostly) and anaerobes (rarely and stay in short life) according to the existing publications [15]. Nonetheless, according to another publication [2], a good condition that Bacillus strain can growth well is in aerobes production and its typical characteristics of the $B$. subtilis is a facultative aerobic, Gram-positive rod, and spore formation. There are three kinds of test for biological counting VPOF test, Manito Salt, and Catalase test. Bacillus species will be positive for the 
enzyme catalase when there has been oxygen. The result has shown that all Bacillus strains are fermented in OF test and all positive in Manito Salt, VP and Catalase test, including B. subtilis, and they were catalase-positive reaction, mannitol, and maltose [2].

\subsubsection{Subject to Assay of Bacillus Subtilis Strains}

Selected 19 strains of B. subtilis have been taken to determine antimicrobial activity against indicator organisms and were determined by using a well diffusion assay method. There was a significant difference among the zone activities $B$. subtilis strain classifications. As an overview on the result, $B$. subtilis strains had antimicrobial activity against indicator organisms of L. plantum bacteria and they mostly had activity at $35{ }^{\circ} \mathrm{C}$ much more than at $30{ }^{\circ} \mathrm{C}$. Further, the $B$. subtilis strains most likely had antimicrobial activity when using un-filtration method. As detail in the result, 6 strains named B. BTM8-9, $B$. TaM2-4(1), B. BTM8-10, B. TSM5-10, B. TSM5-3, B.CKM9-2 did not show any antimicrobial activity, meanwhile, other 4 strains had total zone activities between 6-11 $\mathrm{mm} / \mathrm{mL}$, including $B$. BTM8-4(2), $B$. TaM2-4(2),B. TSM5-8(1), B. TSM5-7, shown less antimicrobial activity, and other 9 remaining between 12-64 mm/mL, B. CeM6-7, B. BTM8-4(1), BTM8-1, CKM9-1, DM1-14(2), DM1-14(1), CKM9-7 and DM1-17 strains have strong activities against indicator organisms in both temperature condition, and both methods (filtration, and without filtration). These 9
Bacillus strains that had strong activities are predicted to be able to suppress the growth of $L$. plantum bacteria, and they were the samples (culture supernatant) in MRS broth with supplement $1 \%$ agar mixed. Finally, only 9 Bacillus strains that had strong activity were selected for the next experiment.

Table 1 exposed that in average size, Bacillus CeM6-7 strain had the largest zone activities presented for $10.67 \mathrm{~mm} / \mathrm{mL}$ L. planum bacteria and the Bacillus BTM8-4(1), TSM5-8(2), CKM9-1, DM1-14(2), DM1-14(1), CKM9-7 and DM1-17 strains had the average zone activities 6.00, 5.83, 4.17, 3.67, 2.83, 2.67, 2.50 and $2.00 \mathrm{~mm} / \mathrm{mL}$, correspondingly.

\subsubsection{Bacteriocin Producing Bacillus Subtilis Strain}

From the previous step, subject to assay of Bacillus strains, one of Bacillus activity strain namely CKM9-7(1) was developed to have one additional strain. We finally obtained purified 10 of Bacillus activities strains.

After receiving high bacteriocin producing Bacillus strains, those 10 strains were gone for further test to isolate the strongest Bacillus subtilis strain which could produce bacteriocin the best in comparing with other strains. The total diameter of zone activity $(\mathrm{mm} / \mathrm{mL})$ for Lactobacillus planum and API50 $\mathrm{CH}$ were used in the context of "measure of the rank and classify Bacteriocin productions on the Bacillus subtilis strain" for final selection of Bacteriocin. The categories, rank and selection of Bacteriocin production

Table 1 Average zone activity $(\mathrm{mm} / \mathrm{ml})$ for lactobacillus planum by type of bacillus strain.

\begin{tabular}{|c|c|c|c|c|c|c|c|c|c|c|}
\hline \multirow[t]{2}{*}{ S.N } & \multirow{2}{*}{$\begin{array}{l}\text { Type of Bacillus } \\
\text { strains }\end{array}$} & \multirow{2}{*}{$\begin{array}{l}\text { Incubator } \\
\text { time }(\mathrm{h})\end{array}$} & \multirow{2}{*}{$\begin{array}{l}\text { Incubator } \\
\text { temperature }\end{array}$} & \multirow{2}{*}{$\begin{array}{l}\text { Incubator } \\
\text { time (hrs) }\end{array}$} & \multirow{2}{*}{$\begin{array}{l}\text { Incubator } \\
\text { temperature }\end{array}$} & \multirow{2}{*}{$\begin{array}{l}\mathrm{N}^{0} \text { respondents } \\
\text { of } \mathrm{B} \text {. activates }\end{array}$} & \multicolumn{4}{|c|}{$\begin{array}{c}\text { Diameter of zone activity }(\mathrm{mm} / \mathrm{ml}) \text { for } \\
\text { Lactobacillus planum bacteria }\end{array}$} \\
\hline & & & & & & & Min & Max & Total & Average \\
\hline 1 & СeM6-7 & 17 & $35^{\circ} \mathrm{C}$ & 24 & $30^{\circ} \mathrm{C}$ & 6 & 5 & 15 & 64 & 10.67 \\
\hline 2 & BTM8-4(1) & 17 & $35^{\circ} \mathrm{C}$ & 24 & $30^{\circ} \mathrm{C}$ & 4 & 5 & 10 & 36 & 6.00 \\
\hline 3 & BTM8-1 & 17 & $35^{\circ} \mathrm{C}$ & 24 & $30^{\circ} \mathrm{C}$ & 5 & 5 & 10 & 35 & 5.83 \\
\hline 4 & TSM5-8(2) & 17 & $35^{\circ} \mathrm{C}$ & 24 & $30^{\circ} \mathrm{C}$ & 4 & 5 & 8 & 25 & 4.17 \\
\hline 5 & CKM9-1 & 17 & $35^{\circ} \mathrm{C}$ & 24 & $30^{\circ} \mathrm{C}$ & 3 & 6 & 9 & 22 & 3.67 \\
\hline 6 & $D M 1-14(2)$ & 17 & $35^{\circ} \mathrm{C}$ & 24 & $30^{\circ} \mathrm{C}$ & 3 & 3 & 7 & 17 & 2.83 \\
\hline 7 & $D M 1-14(1)$ & 17 & $35^{\circ} \mathrm{C}$ & 24 & $30^{\circ} \mathrm{C}$ & 2 & 0 & 8 & 16 & 2.67 \\
\hline 8 & CKM9-7 & 17 & $35^{\circ} \mathrm{C}$ & 24 & $30^{\circ} \mathrm{C}$ & 3 & 0 & 8 & 15 & 2.50 \\
\hline 9 & DM1-17 & 17 & $35^{\circ} \mathrm{C}$ & 24 & $30^{\circ} \mathrm{C}$ & 3 & 3 & 9 & 12 & 2.00 \\
\hline & Total & - & - & - & - & 33 & 32 & 242 & 391 & 97.75 \\
\hline
\end{tabular}


analysis of all types of Bacillus are presented in Table 2.

Table 2 revealed that mean of CeM6-7 strain was $8.50 \mathrm{~mm} / \mathrm{mL}, 71 \%$, which was the highest proportion of total area of zone activity for Lactobacilus planum likened to other strains that we were measured and the following order of Bacillus strain was DM1-14(2), DM1-14(1), CKM9-7(2), CKM9-7(1), BTM8-1, BTM8-4(1), TSM5-8(2), CKM9-1 and DM1-17 strains respectively. The rank and selection of $B$. subtilis strain were based on its size $(\mathrm{mm} / \mathrm{mL})$ and percentage of zone activity that shown the trend for all type $B$. subtilis strains.

Accordingly, only one strain CeM6-7 which had very strong zone activities was selected for further test since it was able to suppress the growth of L. plantum bacteria which it was in parallel with existing researches stated that, some B. Subtilis have reported to produce bacteriocins which suppress the growth of Gram positive spoilage and pathogenic bacteria [17, 18]. In addition, we also found that antimicrobial activity against indicator organism of CeM6-7 was more actively at $35{ }^{\circ} \mathrm{C}$ compared to $30{ }^{\circ} \mathrm{C}$. There are also some strains such as DM1-14(1),DM1-14(2), and CKM9-7(2) which shown antimicrobial activity against indicator organism. However, these strains are half-strong compared to B. CeM6-7 strain. The strains CeM6-7 was identified as B. subtilis by $96.2 \%$ and a T-value (0.76) homology correspondingly counted on API $50 \mathrm{CH}$ V4.1 (BioMérieux) profiles (not shown) and their physiological characteristics.

\subsection{Characterize the Bacteriocin Produced by Isolated Strain}

The result obtained from our test shown B. CeM6-7 strain had ability resistant to heat. Similarly, $B$. subtilis strains may produce other antimicrobial substance, which have been characterized to a much lesser extent [15].

\subsubsection{Incubator Temperature and Timing}

In this test, we used two variables of temperatures $\left(30^{\circ} \mathrm{C}\right.$ and $\left.37^{\circ} \mathrm{C}\right)$ and different timing $(0 \mathrm{~h}, 6 \mathrm{~h}, 8 \mathrm{~h}$ and $12 \mathrm{~h}$ for first day and $0 \mathrm{~h}, 14 \mathrm{~h}, 16 \mathrm{~h}, 18 \mathrm{~h}, 20 \mathrm{~h}$ and $22 \mathrm{~h}$ for second day), and the L. plantum (LP) bacteria was used as the indicator strain. The test was conducted for 2 days.

As seen in Fig. 1, in the first day of test, the antimicrobial activities of bacteriocin were activated at $12 \mathrm{~h}(10 \mathrm{~mm} / \mathrm{mL})$ at $37{ }^{\circ} \mathrm{C}$ only, beside there was no antimicrobial activities at all. The antimicrobial

Table 2 Rank and selection of bacteriocin produced by Bacillus subtilis strain category by total diameter of zone activity ( $\mathrm{mm} / \mathrm{mL}$ ) for Lactobacilusplanum.

\begin{tabular}{|c|c|c|c|c|c|c|c|c|c|c|}
\hline \multirow[t]{2}{*}{ S.N } & \multirow[t]{2}{*}{$\begin{array}{l}\text { Type of } \\
\text { Bacillus } \\
\text { strains }\end{array}$} & \multirow[t]{2}{*}{$\begin{array}{l}\text { Incubator } \\
\text { time (hrs) }\end{array}$} & \multirow[t]{2}{*}{$\begin{array}{l}\text { Incubator } \\
\text { temperature } \\
\left({ }^{\circ} \mathrm{C}\right)\end{array}$} & \multirow{2}{*}{$\begin{array}{l}\text { Total } \mathrm{N}^{0} \\
\text { zone activity } \\
(\mathrm{mm} / \mathrm{mL}) \text { at } \\
30{ }^{\circ} \mathrm{C} \\
\end{array}$} & \multirow[t]{2}{*}{$\begin{array}{l}\text { Incubator } \\
\text { temperature } \\
\left({ }^{\circ} \mathrm{C}\right)\end{array}$} & \multirow{2}{*}{$\begin{array}{l}\text { Total } \mathrm{N}^{0} \text { zone } \\
\text { activity } \\
(\mathrm{mm} / \mathrm{mL}) \text { at } \\
30^{\circ} \mathrm{C}\end{array}$} & \multirow[t]{2}{*}{$\begin{array}{l}\text { Total } \mathrm{N}^{0} \\
\text { respondents of } \\
\text { B. activates }\end{array}$} & \multicolumn{3}{|c|}{$\begin{array}{l}\text { Diameter of zone activity } \\
(\mathrm{mm} / \mathrm{mL}) \text { for Lactobacilus } \\
\text { planum }\end{array}$} \\
\hline & & & & & & & & Total & Mean & Percentage \\
\hline 1 & СeM6-7 & \multirow{10}{*}{ overnight } & \multirow{10}{*}{35} & 28 & \multirow{10}{*}{30} & 6 & 4 & 34 & 8.50 & 71 \\
\hline 2 & $D M 1-14(2)$ & & & ND & & ND & 2 & 5 & 1.25 & 10 \\
\hline 3 & $D M 1-14(1)$ & & & 4 & & ND & 2 & 5 & 1.25 & 10 \\
\hline 4 & CKM9-7(2) & & & ND & & ND & 2 & 4 & 1.00 & 9 \\
\hline 5 & CKM9-7(1) & & & ND & & ND & ND & ND & ND & ND \\
\hline 6 & BTM8-1 & & & ND & & ND & ND & ND & ND & ND \\
\hline 7 & BTM8-4(1) & & & ND & & ND & ND & ND & ND & ND \\
\hline 8 & TSM5-8(2) & & & 3 & & 2 & ND & ND & ND & ND \\
\hline 9 & CKM9-1 & & & 3 & & 2 & ND & ND & ND & ND \\
\hline 10 & DM1-17 & & & ND & & ND & ND & ND & ND & ND \\
\hline \multicolumn{2}{|c|}{ Total } & & - & 38 & - & 10 & 10 & 48 & - & 100.00 \\
\hline
\end{tabular}

Note: Not detected (ND). 


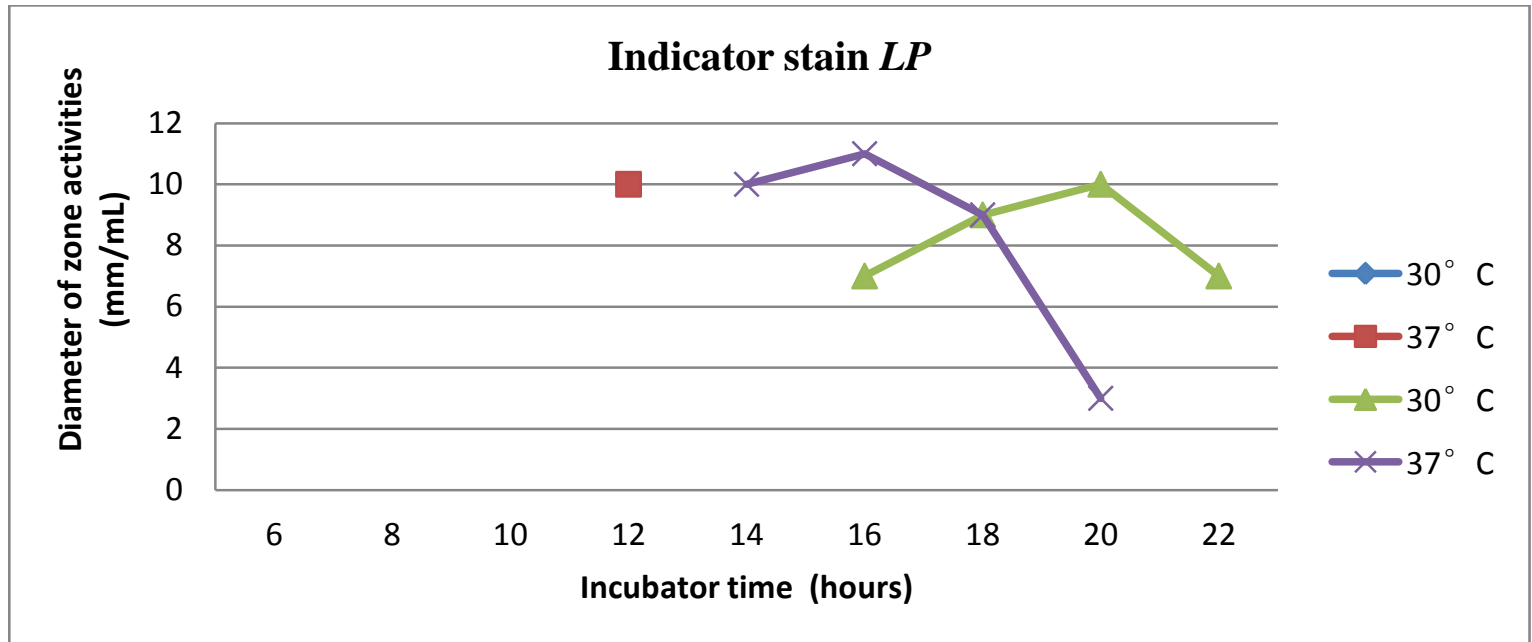

Fig. 1 Effect of difference incubator temperature and timing on the activity of bacteriocin produced by $B$. subtilis CeM6-7 strain.

activities were actively happened in the second day of test. In the same figure and table revealed that the antimicrobial activities of bacteriocin started to be active after $16 \mathrm{~h}$ of incubation at $30{ }^{\circ} \mathrm{C}$. The antimicrobial activities kept increasing consistently for four hours, and gradually decrease after $20 \mathrm{~h}$ of incubation at $30^{\circ} \mathrm{C}$. At $37{ }^{\circ} \mathrm{C}$, the bacteriocin started increasing its antimicrobial activities after $14 \mathrm{~h}$ of incubation which was faster compared with $30{ }^{\circ} \mathrm{C}$ of incubation temperature. Though, its antimicrobial activity was kept increasing slightly for just only two hours, and started decreasing sharply for the next four hours until became inactivated after $20 \mathrm{~h}$ of incubation at $37{ }^{\circ} \mathrm{C}$. It demonstrated that bacteriocin produced by CeM6-7 strain is more likely to be active at $37{ }^{\circ} \mathrm{C}$ for a longer period compared with its activities at $30{ }^{\circ} \mathrm{C}$ for two tested days. The finding was similar to previous researches that indicated the behavior of bacteriocin towards heat-resistant pathogens also varies [8]. Additional finding, at $37{ }^{\circ} \mathrm{C}$, Bacillus CeM6-7 strain could tolerate with heat up to $16 \mathrm{~h}$, which was higher toleration than at $30{ }^{\circ} \mathrm{C}$, and it still had ability to fight against indicator strain $L P$.

\subsubsection{Soybean Milk Treatment}

In this test, we used the enzyme contained in soybean milk as the treatment, and used four types of indicators including $L$. plantum (LP), Lev. mesentanides (LM), S. aureus. (SA), and M. luceus Spi-flams $(M L)$. We also used other five of bacteriocin producing by Bacillus subtil strains including, $B$. CeM6-7, and Miyagino (control strain) for comparing the result.

A. Indicator Strain $L P$

In Fig. 2, presented the characteristics of antimicrobial activity against $L P$ by $B$. subtilis stains such as $B$. CeM6-7 (isolated from traditional fermented soybean (SEING)), and Miyagino after cultured in Bacillus-Soybean milk broth contained against LP (dilution of 103 times). The result shown that the stain B. CeM6-7 produced the strongest antimicrobial activity against Bacillus-Soybean milk broth contained LP compared with Miyagino, but the other remaining strains B. CeM6-7 and Miyagino, were found to be no antimicrobial activity at all. At $0 \mathrm{~h}$, all strains were counted to be $3.33 \log 10 \mathrm{CFU} / \mathrm{mL}$ equally. At $3 \mathrm{~h}$ and 6 $\mathrm{h}$, the B. CeM6-7 was calculated to be $2.643 \log 10$ $\mathrm{CFU} / \mathrm{mL}$ to $3.204 \log 10 \mathrm{CFU} / \mathrm{mL}$ and at $9 \mathrm{~h}$ was calculated $2.623 \log 10 \mathrm{CFU} / \mathrm{mL}$ respectively, which in comparison were less than Miyagino that presented at $3.794 \log 10 \mathrm{CFU} / \mathrm{mL}$ to $4.549 \log 10 \mathrm{CFU} / \mathrm{mL}$ and $4.853 \log 10 \mathrm{CFU} / \mathrm{mL}$ at $9 \mathrm{~h}$ correspondingly.

\section{B. Indicator Strain $L M$}

In Fig. 3 introduced the characteristics of antimicrobial activity of Bacillus subtilis CeM6-7 strains, 


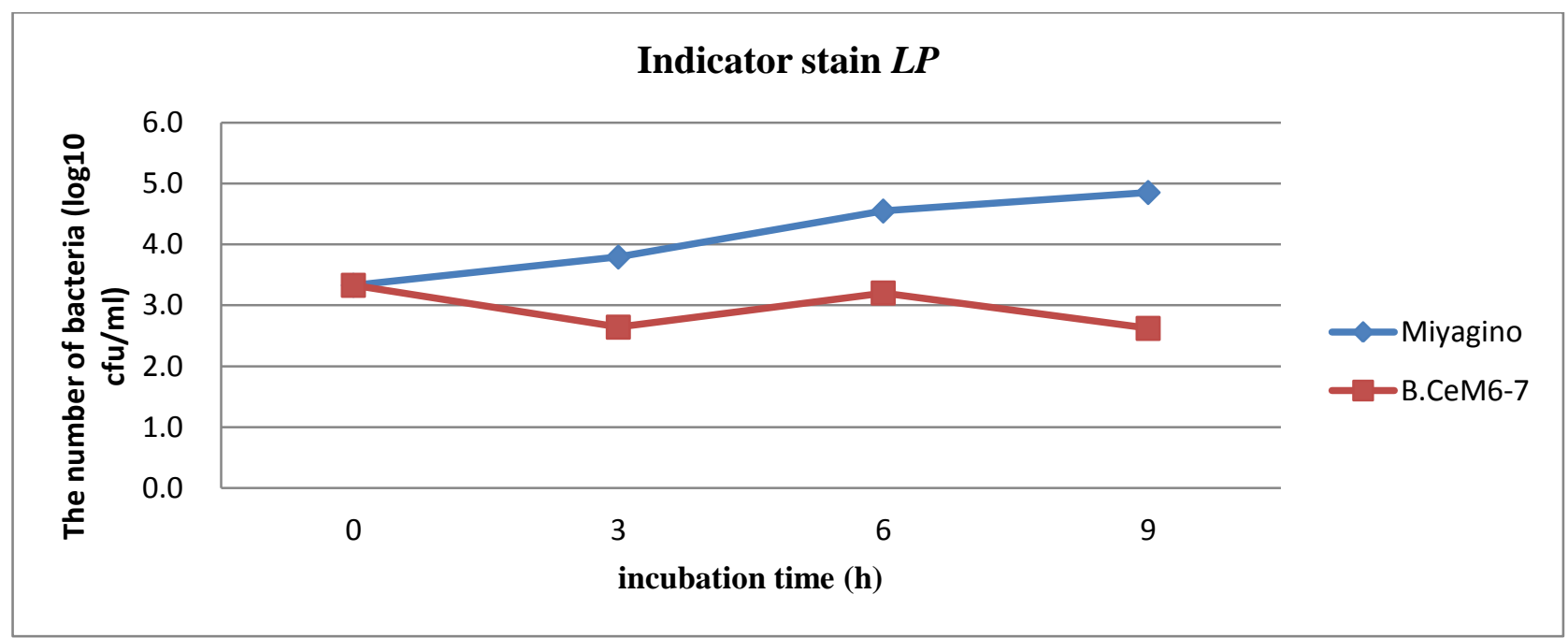

Fig. 2 Enzymes of soybean milk resistant for strain bacillus CeM6-7 compare with Miyagino strains against indicator $L P$.

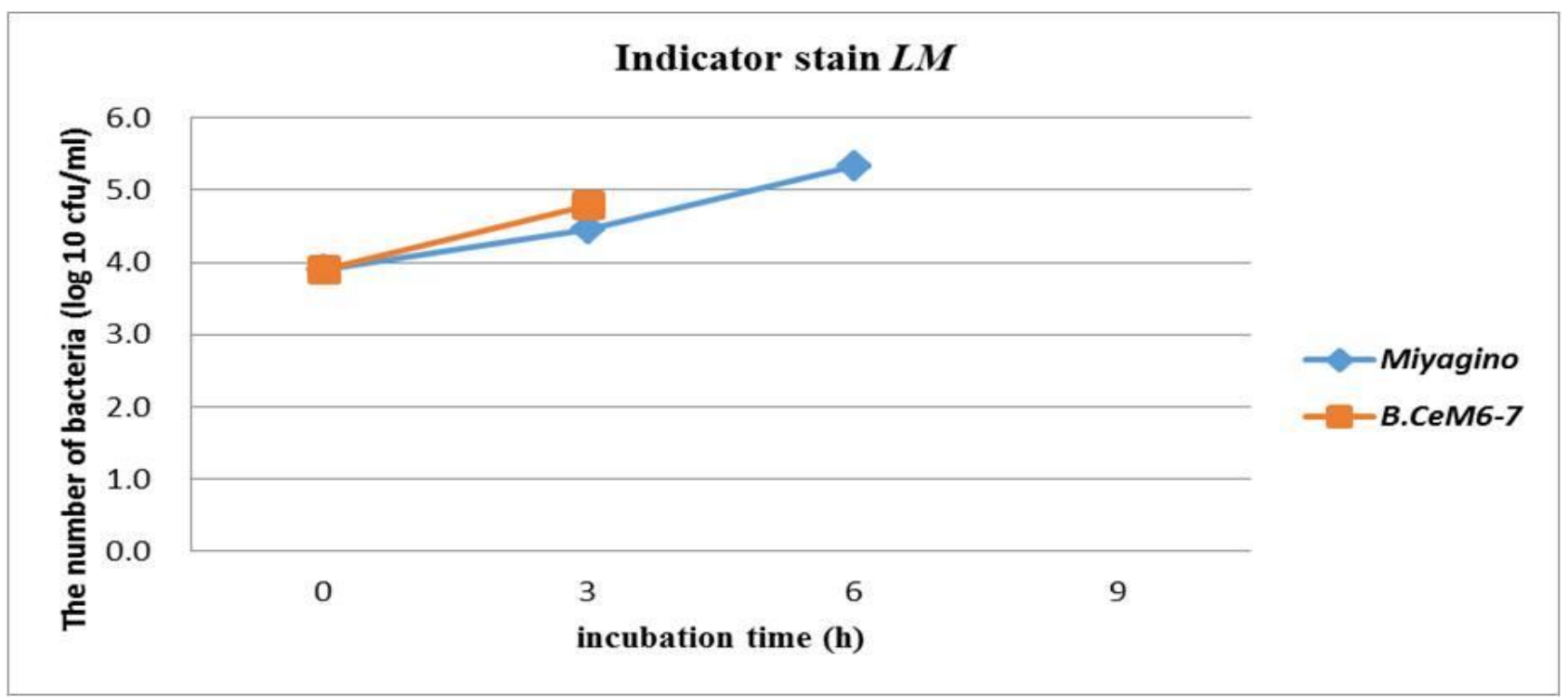

Fig. 3 Enzymes of soybean milk resistant for strain bacillus CeM6-7 compare with Miyagino strains against indicator $L M$.

and Miyagino against $L M$ indicator strain after cultured in Bacillus-Soybean milk broth contained against $L M$ (dilution of 103 times). As the result, the $B$. Ce6-7 stains no powerful antimicrobial activity with against $L M$ at $3 \mathrm{~h}$ to $9 \mathrm{~h}$ incubation timing, since it was counted to be $4.795 \log 10 \mathrm{CFU} / \mathrm{mL}$ to $\mathrm{MPN}$, which were less than Miyagino $(4.461 \log 10 \mathrm{CFU} / \mathrm{mL}$ to $5.336 \log 10 \mathrm{CFU} / \mathrm{mL}$ ) at $3 \mathrm{~h}$ to $6 \mathrm{~h}$.

\section{Indicator Strain $S A$}

The characteristics of antimicrobial activity against $S A$ of five strains B. subtilis and Miyagino after cultured in Bacillus-Soybean milk broth contained against $S A$ (dilution of 103 times) were discussed in Fig. 4.

The figure indicated that at $3 \mathrm{~h}$ to $6 \mathrm{~h} \mathrm{B.} \mathrm{CeM6-7}$ strains had antimicrobial activity able to inactivate Bacillus-Soybean milk broth contained against $S A$. At these two incubation timing, $3 \mathrm{~h}$ and $6 \mathrm{~h}, B$. CeM6-7 strain showed the most powerful antimicrobial action compared to Miyagino strains. At $9 \mathrm{~h}$, there was no antimicrobial activity shown. The B. CeM6-7 and Miyagino strains cultured growing between 3.785 $\log 10 \mathrm{CFU} / \mathrm{mL}$ at $0 \mathrm{~h}$. At $3 \mathrm{~h}$, the antimicrobial produced by $B$. CeM6-7 strains were developed between 


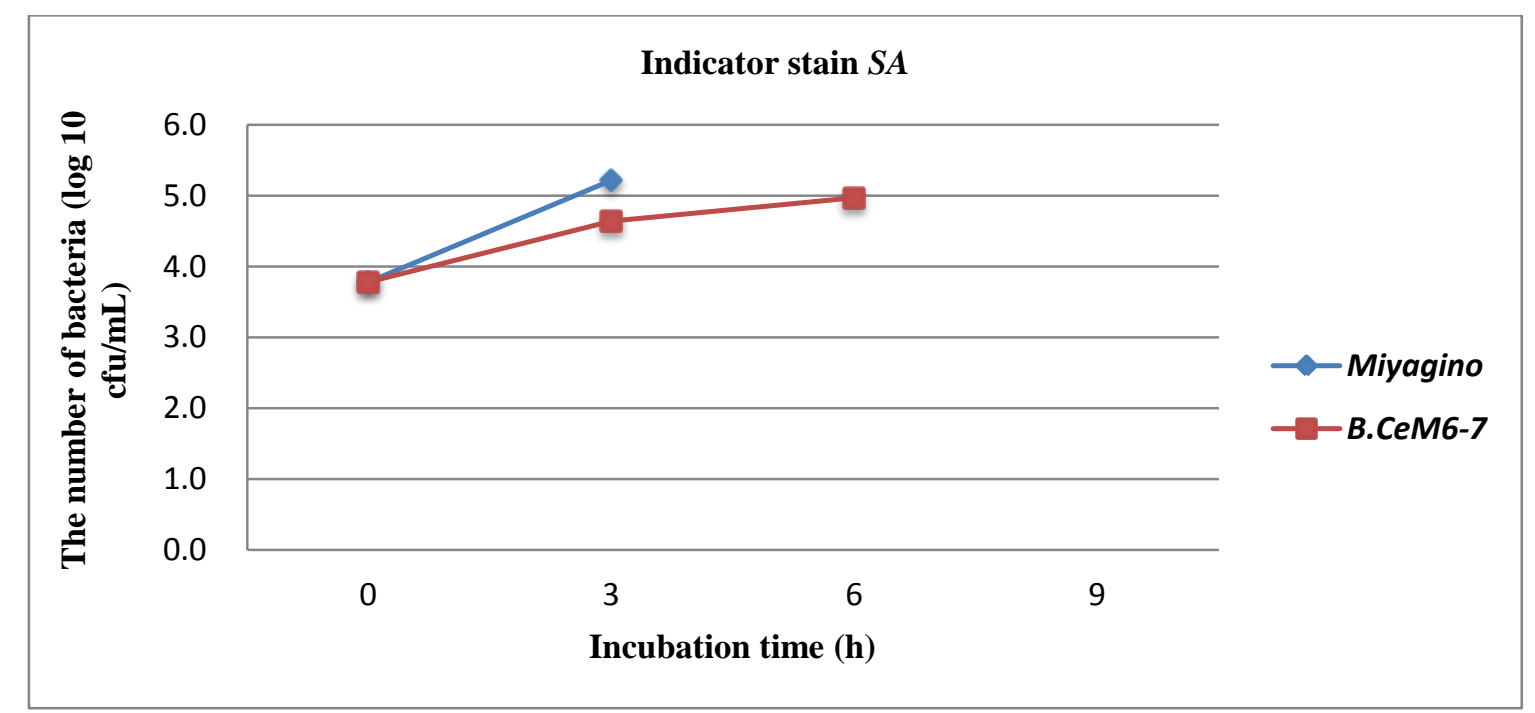

Fig. 4 Enzymes of soybean milk resistant for bacillus CeM6-7 strain compare with other strains against indicator $S A$.

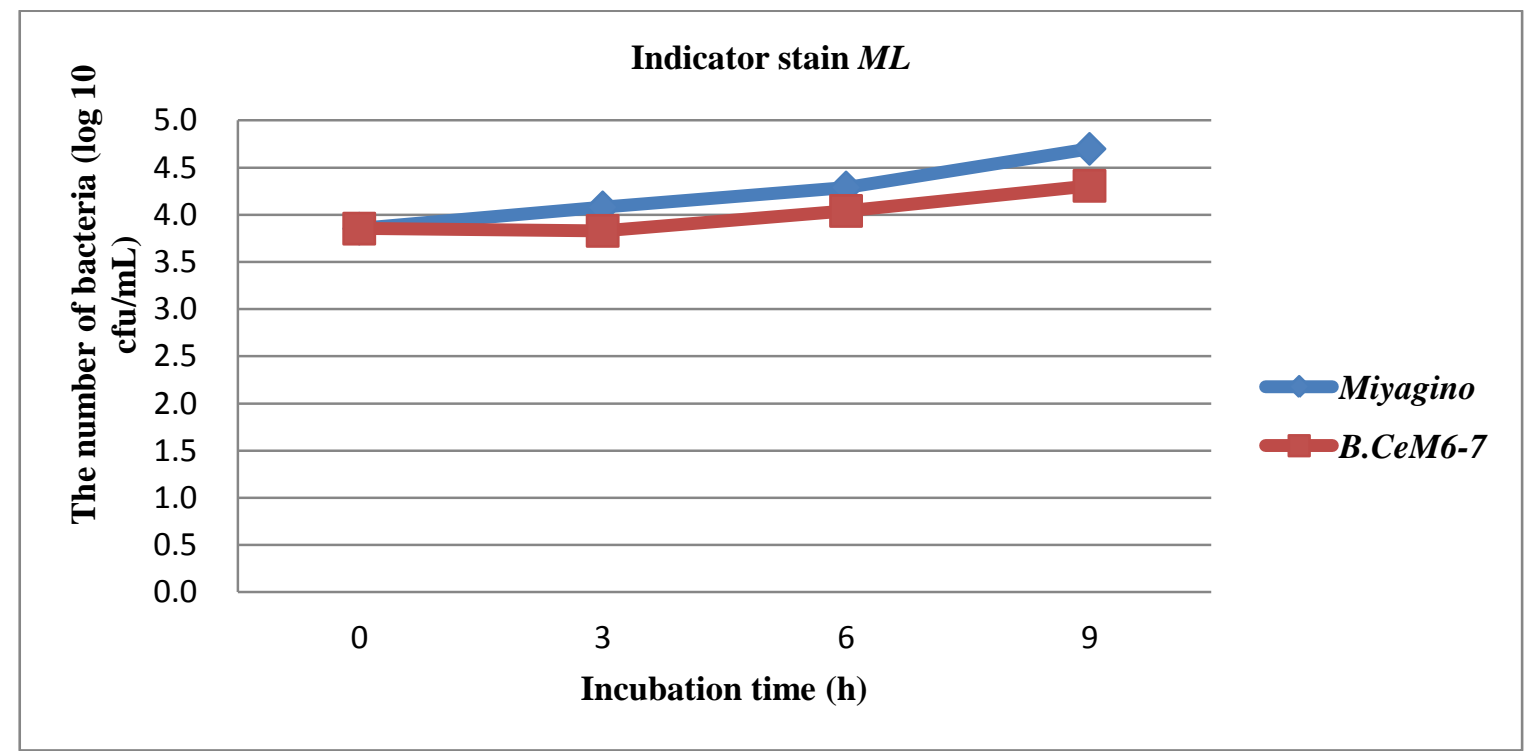

Fig. 5 Enzymes of soybean milk resistant for bacillus CeM6-7 strain compare with Miyagino strains against indicator ML.

4.641 and $4.641 \log 10 \mathrm{CFU} / \mathrm{mL}$ which less than Miyagino strain was calculated to be $5.220 \log 10$ $\mathrm{CFU} / \mathrm{mL}$. At $6 \mathrm{~h}$ inoculation, Miyagino strain was counted at MPN that higher than the $B$. CeM6-7 strains existed $4.973 \log 10 \mathrm{CFU} / \mathrm{mL}$.

D. Indicator Strain $M L$

In Fig. 5, the characteristics of antimicrobial activity against $M L$ of $B$. CeM6-7 and Miyagino strains after culturing in Bacillus-Soybean milk broth contained against $M L$ (dilution of 103 times) were presented. It was indicated that, at different timing (3 h, $6 \mathrm{~h}$, and $9 \mathrm{~h}$ ), the B. CeM6-7 strain had enough ability to fight against Bacillus-Soybean milk broth contained $M L$ compared to strain Miyagino, but it's more likely be less action. The B. CeM6-7 strain cultured and grew the same amount at $3.854 \log 10$ $\mathrm{CFU} / \mathrm{mL}$ at $0 \mathrm{~h}$ inoculation and it was increased 3.830-4.407 $\log 10 \mathrm{CFU} / \mathrm{mL}$ at $3 \mathrm{~h}$ to $9 \mathrm{~h}$ incubation time. The amount of B. CeM6-7 strain cultured and grew in each timing, $3 \mathrm{~h}, 6 \mathrm{~h}$ and $9 \mathrm{~h}$ were automatically smaller than Miyagino strain that was 4.079, 4.290, and 4.699 $\log 10 \mathrm{CFU} / \mathrm{mL}$ respectively.

In short, the $B$. CeM6-7 strain performed very well when treated with enzyme, especially for 
Bacillus-Soybean milk broth contained against SA, while they were the most powerful to fight against Bacillus-Soybean milk broth contained against $L P$, but the antimicrobial activity of $B$. CeM6-7 strain against $M L$ indicator were found to be in less power (not much different), although they were significant different from Miyagino strain.

3.3.3 Evaluation of Characteristic of the Bacteriocin Producing by Bacillus Subtilis

Table 3 revealed that B. CeM6-7 strains had powerful antimicrobial activities zone which presented for $375 \mathrm{AU} / \mathrm{mL}$ with against $S A$, but they were very higher activities zone than indicator against $P L$ and $M L$ and $L M$, which $B$. CeM6-7 strain that was existed $275 \mathrm{AU} / \mathrm{mL}$ and $75 \mathrm{AU} / \mathrm{ml}$ and for $L M$ indication, B. CeM6-7 strain shown none bio-control activity, correspondingly. Meanwhile, in $S A$ indication B. CeM6-7 was most powerful to fight against indicator. Nonetheless, other remaining strains did not show any action with indicator against $L M$. Eventually, in $M L$ indicator, B. CeM6-7 had a weak positive antimicrobial activity against the indicator strain comparing of the Miyagino strain (not detected). Therefore, B. CeM6-7 had its powerful antimicrobial activities against uniquely $S A$ indicator strain at a very significant level.

On the other hand, the existed results also show the complexity of microbiological flora in the products which was reflected wisely biological diversity of the natural environments used in the fermentation process, suggesting the potential value of traditional fermented foods as natural resources of bacteria and enzymes for industrial application. Likewise, Cambodian fermented soybean (SIENG) is similar to Thua nao in Thailand that make from fermented soybean. In fact, strains in the Thua nao (Bacillus strains) produced in northern Thailand exhibited complex microflora and molecular diversity [2].

\subsection{Optimize the Condition of the Bacteriocin Production}

The optimization the condition of the bactoriocin production was conducted to be fully understand about the whole process of antimicrobial activity against four indicator strains ( $L P, L M, S A$ and $M L)$ of all our five tested strains comparing with Miyagino strain after culturing in MRS broth with $1 \%$ agar purified powder contained against $L P$ and $L M$; and TSA agar containing against $S A$ and $M L$ (dilution of 104 times). All five tested strains and Miyagino strain were diluted in three differences times (102, 104, and 106) and counted spore culture prior to start experiment.

\subsubsection{Counting the Colony of Two B. Subtilis}

Table 4 indicated that there was non-significant different between the colony of spore culture of $B$.

Table 3 Evaluation of characteristic of isolated bacteriocin activity by using bacteriocin bioassay by AU (arbitrary unit).

\begin{tabular}{|c|c|c|c|c|c|c|c|c|c|c|}
\hline \multirow{2}{*}{$\begin{array}{l}\text { Type of } \\
\text { Bacillus } \\
\text { strains }\end{array}$} & \multirow{2}{*}{$\begin{array}{l}\text { Incubator } \\
\text { temperature }\end{array}$} & \multirow{2}{*}{$\begin{array}{l}\text { Incubator } \\
\text { time }\end{array}$} & \multicolumn{2}{|c|}{$\begin{array}{l}\text { Diameter of the } \\
\text { inhibition-zone for } L P\end{array}$} & \multicolumn{2}{|c|}{$\begin{array}{l}\text { Diameter of the } \\
\text { inhibition-zone for } L M\end{array}$} & \multicolumn{2}{|c|}{$\begin{array}{l}\text { Diameter of the } \\
\text { inhibition-zone for } S A\end{array}$} & \multicolumn{2}{|c|}{$\begin{array}{l}\text { Diameter of the } \\
\text { inhibition-zone for } M L\end{array}$} \\
\hline & & & $\mathrm{mm} / \mathrm{mL}$ & $\mathrm{AU} / \mathrm{mL}$ & $\mathrm{mm} / \mathrm{mL}$ & $\mathrm{AU} / \mathrm{mL}$ & $\mathrm{mm} / \mathrm{mL}$ & $\mathrm{AU} / \mathrm{mL}$ & $\mathrm{mm} / \mathrm{mL}$ & $\mathrm{AU} / \mathrm{mL}$ \\
\hline Miyagino & $35^{\circ} \mathrm{C}$ & & ND & ND & ND & ND & ND & ND & ND & ND \\
\hline В.СеМ6-7 & & veniाngाt & 11.00 & 275.00 & 0.00 & 0.00 & 15.00 & 375.00 & 3.00 & 75.00 \\
\hline
\end{tabular}

Note: Not detected (ND).

Table 4 Comparison of average colony counts obtained from Petri films between 2 kinds of Bacillus subtilis using one way ANOVA.

\begin{tabular}{|c|c|c|c|c|c|c|}
\hline \multirow{2}{*}{$\begin{array}{l}\text { Type of bacillus } \\
\text { strains }\end{array}$} & \multicolumn{6}{|c|}{ Parameters of bacillus subtilis } \\
\hline & $\begin{array}{l}\text { Dilution of } 10^{2} \text { times } \\
(\log 10 \mathrm{CFU} / \mathrm{mL})\end{array}$ & $\begin{array}{l}\text { Dilution of } 10^{4} \text { times } \\
(\log 10 \mathrm{CFU} / \mathrm{mL})\end{array}$ & $\begin{array}{l}\text { Dilution of } 10^{6} \text { times } \\
(\log 10 \mathrm{CFU} / \mathrm{mL})\end{array}$ & $\mathrm{n}$ & $\bar{X}$ & $\mathrm{~S} \pm$ \\
\hline Miyagino & 5.556 & 5.292 & 5.230 & 3 & 5.359 & 0.173 \\
\hline B.СеМ6-7 & 5.497 & 4.870 & 4.630 & 3 & 4.999 & 0.447 \\
\hline F-value & & & & & 1.694 & \\
\hline Sig & & & & & 0.263 & \\
\hline
\end{tabular}


CeM6-7 and Miyagino strain $(\mathrm{Sig}=0.263)$ in the three different timing of dilution $(102,104$, and 106) on its bacillus subtilis growth.

3.4.2 Production of Bacteriocin at Different Incubation Timing

Incubation time and temperature play a vital role in bacteriocin production. Therefore, the modification test was conducted using LB broth and incubation at $30{ }^{\circ} \mathrm{C}$ with different timing $(0 \mathrm{~h}, 16 \mathrm{~h}, 20 \mathrm{~h}$ and $23 \mathrm{~h}$ ) and diluted 104 times only. Within the expectation, Bacillus subtilis is capable to produce bacteriocin to fight against four indicator strains finally. The details are presented in Fig. 6. The results were shown the antimicrobial production was begun at $16 \mathrm{~h}$ incubation with $B$. CeM6-7 strain that was able to fight against MRS broth contained LP indicator strain. The bacteriocin production of $B$. CeM6-7 strains, were very active to kill all four indicator strains at $20 \mathrm{~h}$ counted between 175-325 AU/mL. At $23 \mathrm{~h}$ incubation, the antimicrobial production of tested strains had the most power to kill four indicator strains and its bacteriocin productive volume was listed respectively from strong to low, B. CeM6-7, and calculated between 163-275 AU/mL. Controlled strain, Miyagino, was found no action in both MRS broths and TSA agar containing $L P, L M, S A$ and $M L$ against indicator.

In similar finding to the prior test, at $30{ }^{\circ} \mathrm{C}, B$. CeM6-7 stain had highest ability to fight again $L P$ indicator strain beginning from $20 \mathrm{~h}$ incubation to $23 \mathrm{~h}$ incubation and it was the best to kill $L M$ and $M L$ indicator at $20 \mathrm{~h}$ incubation as well. However, B. CeM6-7 stain had a similar powerful to fight against $S A$ and $M L$ indicator strain at the incubated time $(23 \mathrm{~h})$. At the meantime, B. CeM6-7 stain produced the largest amount of bateriocin to be inactivating $S A$ and $M L$ indicator at $23 \mathrm{~h}$ incubation as well. We therefore found that, the productivity of antimicrobial production of tested strains including B. CeM6-7, seem to be in parallel direction with incubation timing. It means that, the longer incubation time (in specific incubation timing) produce the higher bacteriocin.

3.5 Apply the Bacteriocin to Control the Growth of Gram Positive Pathogenic or Spoilage Bacteria in Foods

Applying bacteriocin to control the growth of Gram positive pathogenic or spoilage bacteria and Lactic acid group in foods was conducted against three indicator strains such as $S$. aureus, Listeria and L. brevis, and Lactic acid group (L. plantum, Lb. lactis

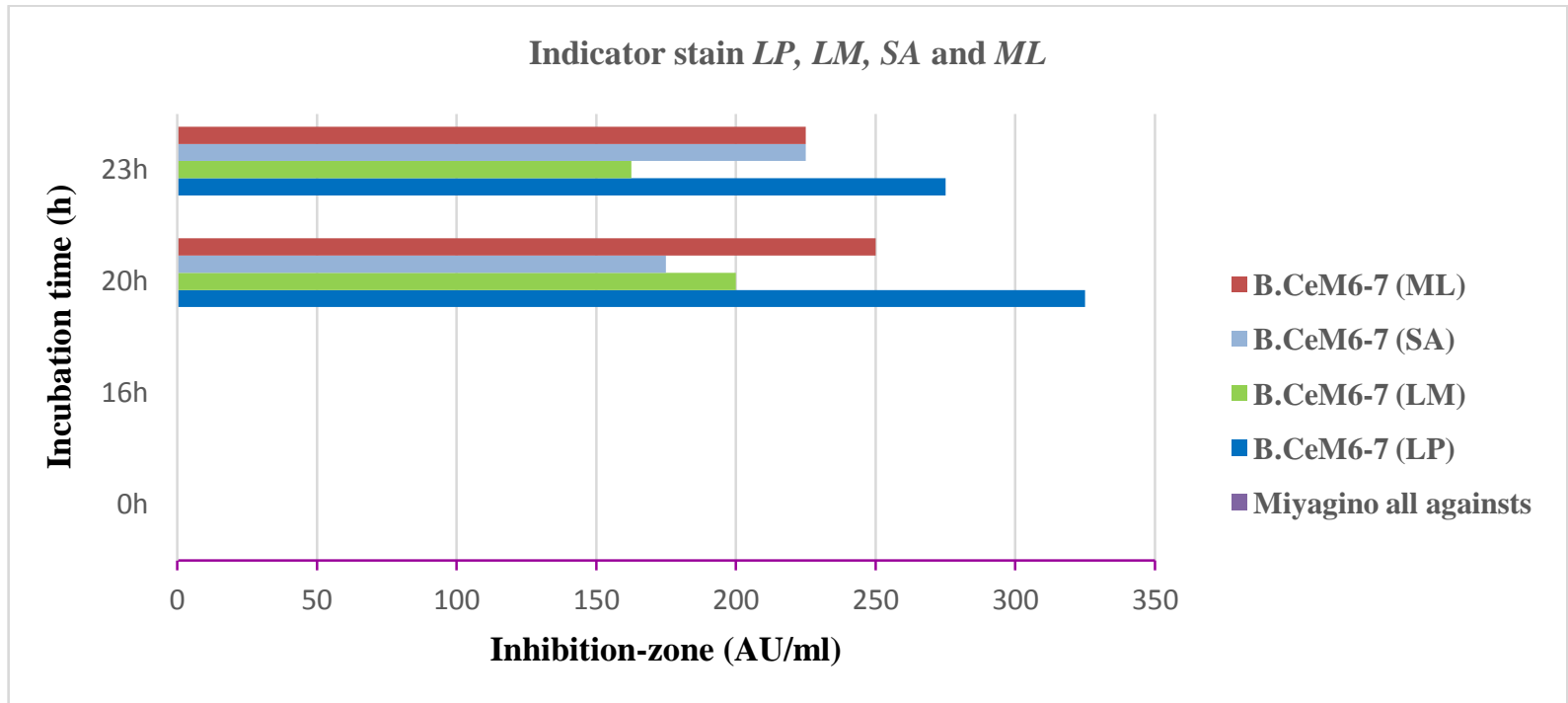

Fig. 6 Production of bacteriocin at different incubation time for Bacillus CeM6-7 strain compare with Miyagino strains non-producing bacteriocin against different indicators. 
and Lactococcus lactis subsp. lactis (produced Nisin A)) contained B. CeM6-7 comparing with Miyagino strain after culturing in HBI contained against Gram positive; and MRS containing against Lactic acid group $(\mathrm{O} . \mathrm{D}=0.1,650 \mathrm{~nm})$, and volume measurement culture prior to start experiment. Similarity searches with sequences in the bacteriocin produced by Bacillus subtilis strain LFB112 from Chinese herbs, was effective against both Gram-positive and Gram-negative bacteria involved in domestic animal diseases [14].

\subsubsection{Gram Positive Group}

In order to study the growth controlling of Gram positive pathogenic or spoilage bacteria in foods of antimicrobial compound of the two kinds of $B$. subtilis group B. CeM6-7 and Miyagino growth, the inhibitory activity present in cell-free samples taken at different time intervals was measured. Antibacterial activity could be detected at the mid-log growth phase and quickly extended a maximum at the early inactive phase, subsequently, the antagonistic activity declined.

\section{A. Indicator strain Staphylococcus aureus}

As shown in Fig. 7, presented the control bacteriocin activity against $S$. aureus by $B . C e M 6-7$ (reference strains producing bacteriocin) and
Miyagino after cultured in HBI broth contained against $S$. aureus $(\mathrm{O} . \mathrm{D}=0.1,650 \mathrm{~nm})$ at $35^{\circ} \mathrm{C}$ for 30 h. At 0 h, B. CeM6-7 was calculated to be 0.06 O.D. higher than Miyagino (0.05 O.D). Until $160 \mathrm{~min}$ (2: $40 \mathrm{~h})$ and 1,800 $\mathrm{min}(30 \mathrm{~h})$, B. CeM6-7 was calculated to be 0.27 and 0.62 O.D respectively, which were less than Miyagino that presented at 0.48 and 0.99 O.D correspondingly. In general, from $160 \mathrm{mn}(2: 40 \mathrm{~h})$ to $1,800 \mathrm{mn}(30 \mathrm{~h})$, the result shown that the stain $B$. CeM6-7 produced the strongest antimicrobial activity against HBI broth contained S. aureus in compared with Miyagino strain.

B. Indicator strain Listeria

The control of antimicrobial activity against Listeria of two strains B. subtilis and Miyagino after cultured in BHI broth contained against Listeria O.D $=0.1,650 \mathrm{~nm})$ at $35{ }^{\circ} \mathrm{C}$ for $30 \mathrm{~h}$, were discussed in Fig. 8. The figure indicated that at $0 \mathrm{~min}(0 \mathrm{~h})$, both strains did not have antimicrobial activity and their O.D was equally 0.03 . Nevertheless, at $185 \min (3 \mathrm{~h})$, the strains B. CeM6-7 was able to inactivate BHI broth contained against Listeria and it was developed to 0.13 O.D less than Miyagino strain at 0.15 O.D. At 1,150 $\mathrm{min}(19 \mathrm{~h})$ and 1,800 $\mathrm{min}(30 \mathrm{~h})$, the B. CeM6-7 was calculated 0.07 O.D and 0.03 O.D respectively, which were less than Miyagino that presented for 0.09

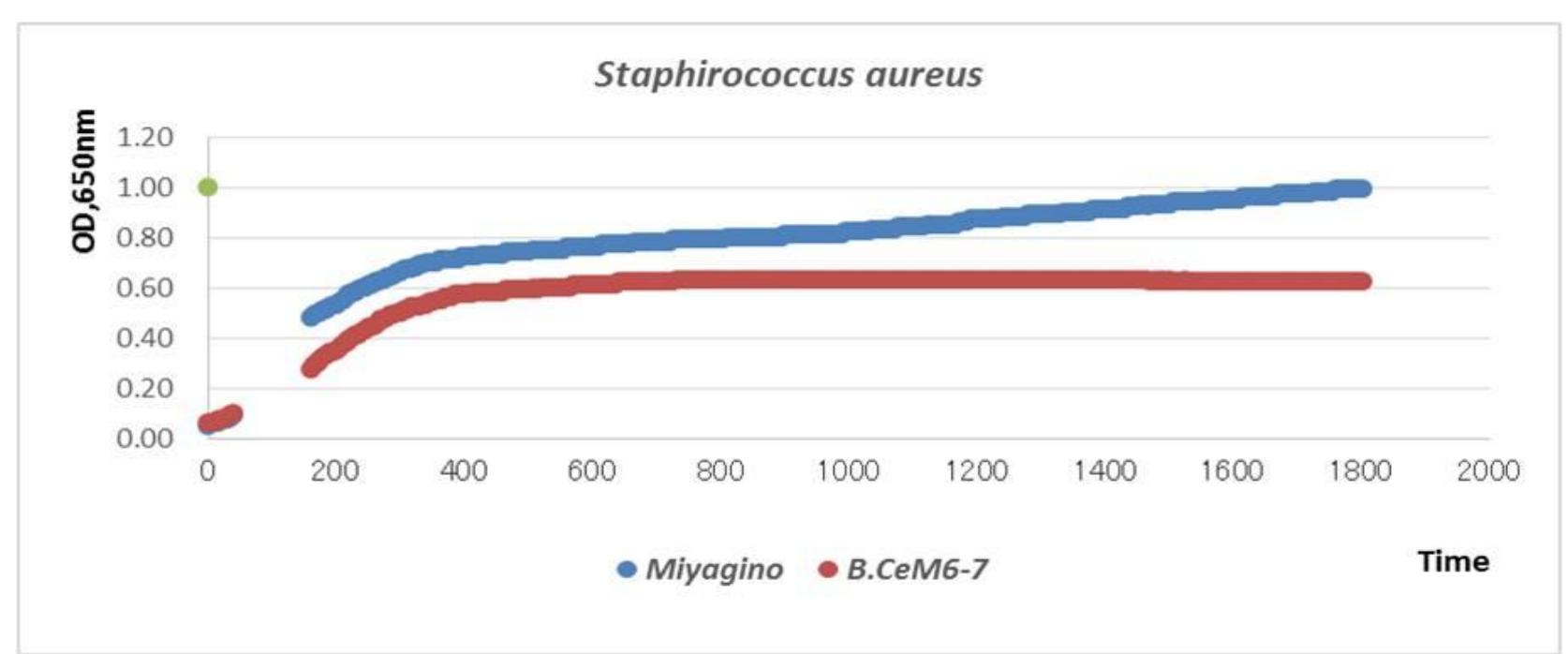

Fig. 7 Effect of bacteriocin produced by B. CeM6-7 strain on the growth of $S$. aureus compare to Miyagino at different time in BHI broth at $35^{\circ} \mathrm{C}$ for $30 \mathrm{~h}$. 


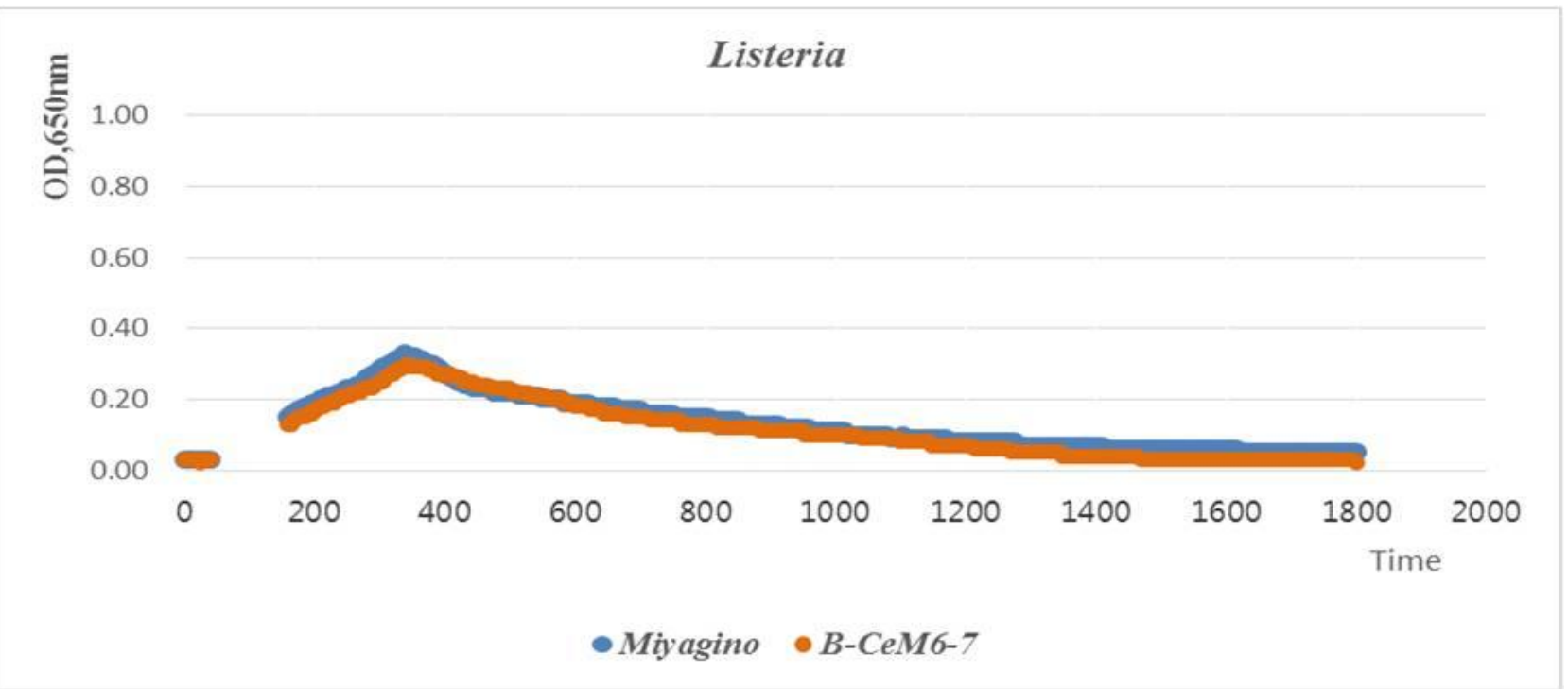

Fig. 8 Effect of bacteriocin produced by B. CeM6-7 strain on the growth of Listeria compare with Miyagino at different time in BHI broth at $35^{\circ} \mathrm{C}$ for $30 \mathrm{~h}$.

to 0.05 O.D correspondingly. In short, from $160 \mathrm{~min}$ (2: $40 \mathrm{~h}$ ) to $1,800 \mathrm{~min}(30 \mathrm{~h})$, B. CeM6-7 strain shown the most powerful antimicrobial action compare to Miyagino (Fig. 8).

\section{Indicator Strain L. brevis}

In commonly, the bacteriocin produced by Bacillus strains against were stable within wide range of $\mathrm{pH}$ values from 3.923 to 4.058 , and non-significant different between the $\mathrm{pH}$ values. The effects of heat, $\mathrm{pH}$, nutritional composition and incubation time at $35{ }^{\circ} \mathrm{C}$ and the antibacterial substances were stable within OD, $650 \mathrm{~nm}(0)$, the $B$. CeM6-7 against. There were exceptions in the case of the Miyagino strain. This strain did not inhibit $L$. brevis at a temperature of $35^{\circ} \mathrm{C}, 25 \mathrm{~h}$ and it was using as control strain.

In Fig. 9 indicated that at $0 \mathrm{~min}(0 \mathrm{~h})$ to $60 \mathrm{~min}(1 \mathrm{~h})$ all of strains, did not had antimicrobial activity. Nevertheless, at $60 \mathrm{~min}(1 \mathrm{~h})$ to $800 \mathrm{~min}(13: 33 \mathrm{~h}), B$. CeM6-7 cultured growing between 0.03 to 0.91 O.D higher than Miyagino 0.03 to 0.88 O.D. After that, CeM6-7 strain was powerless in antibacterial against $L$. brevis at $800 \mathrm{~min}(13: 33 \mathrm{~h})$ to $1,500 \mathrm{~min}(25 \mathrm{~h})$ the antimicrobial activity was almost the same with Miyagino (0.91-0.90 O.D) compared to (0.87-0.90 O.D). Consequently, B. CeM6-7 did not inhibit $L$. brevis at a temperature of $35^{\circ} \mathrm{C}, 25 \mathrm{~h}$.
In short, the Bacillus CeM6-7 strain performed very well when treated with Gram positive group, especially for HBI broth contained against $S$. aureus was the most powerful to fight against MRS broth, but the antimicrobial activity of $B$. subtilis strains against Listeria indicator were found to be no power to suppress and against $L$. brevis indicator was impossible, although it was significant different from Miyagino strain, which it was in parallel with existing researches stated that, some Bacillus Subtilis have reported to produce bacteriocins which suppress the growth of Gram positive spoilage and pathogenic bacteria $[17,18]$.

\subsubsection{Lactic Acid Groups}

In this test, we used two variables of temperature $35^{\circ} \mathrm{C}$ and incubator timing $25 \mathrm{~h}$, and the three kinds of antibacterial produced by B. subtilis CeM6-7 of the tested strains comparing with Miyagino strain after culturing in MRS containing against Lactic acid group (L. plantum, Lb. lactis and Lactococcus lactis subsp. lactis (produced Nisin A) with O.D =0.1, $650 \mathrm{~nm}$ ), bacteria was used as the indicator strain. However, the test was conducted to measure $\mathrm{pH}$ value of each indicators of bacteriocin produced by $B$. subtilis strains culture prior to start experiment and the effects of heat, $\mathrm{pH}$, nutritional composition and incubation 


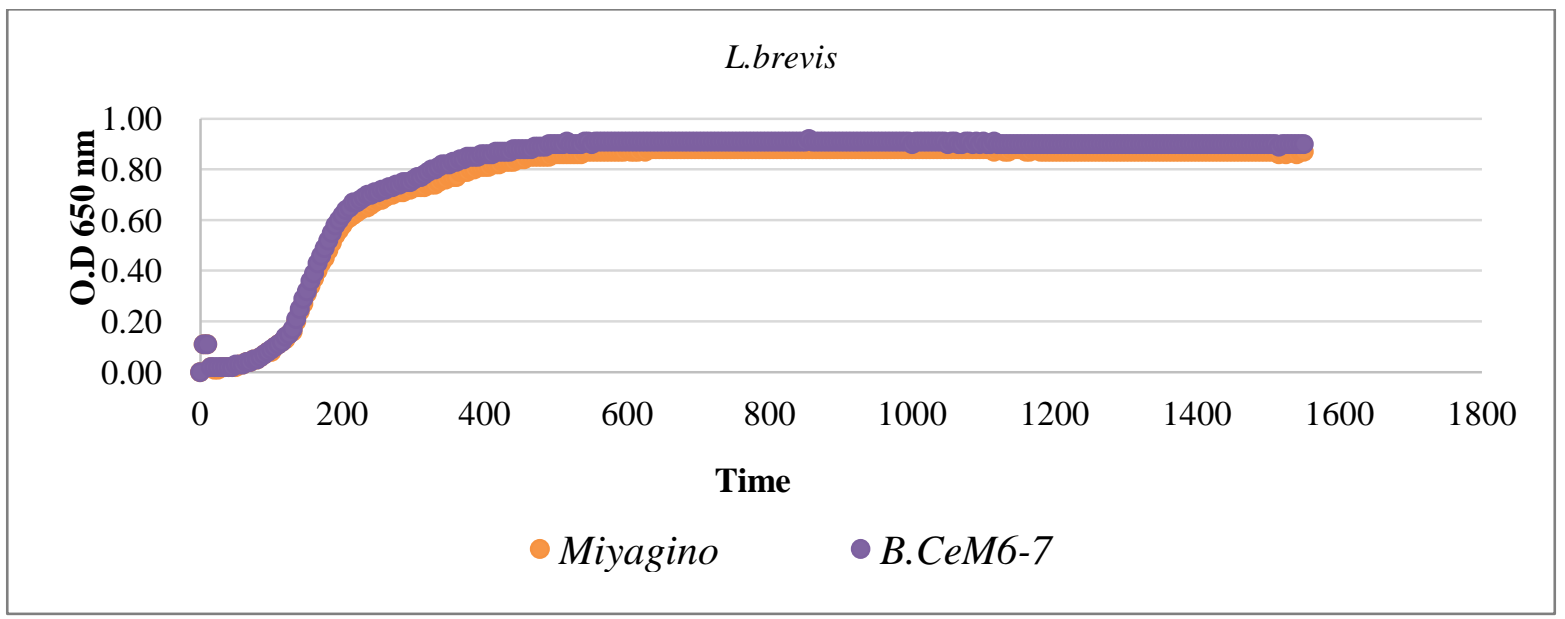

Fig. 9 Effect of bacteriocin produced by B. CeM6-7 strain on the growth of L. brevis compare between Miyagino at different time in MRS broth at $35^{\circ} \mathrm{C}$ for $25 \mathrm{~h}$.

time at $35{ }^{\circ} \mathrm{C}$ and the antibacterial substances were stable within O.D, $650 \mathrm{~nm}$ and wide range $\mathrm{pH}$ value from 3.858 to 3.923 as shown by the isolates strain against on inhibitory by the bacteriocin producing form B. CeM6-7 strains was compared with Miyagino strain to be using control strain in cell-free samples taken at different time intervals was measured. Antibacterial activity could be detected at the mid-log growth phase and quickly extended a maximum at the early inactive phase, subsequently, the antagonistic activity declined.

\section{A. Indicator Strain L. plantum}

In generally, the antibacterial produced by $B$. CeM6-7 strains agents were stable within wide range of $\mathrm{pH}$ values from 3.923 to 4.058 . The effects of heat, $\mathrm{pH}$, nutritional composition and incubation time at $35{ }^{\circ} \mathrm{C}$ and the antibacterial substances were stable within O.D, $650 \mathrm{~nm}$ of B. CeM6-7. There were exceptions in the case of the Miyagino strain. This strain did not inhibit $L$. plantum at a temperature of $35^{\circ} \mathrm{C}, 25 \mathrm{~h}$ and it was using as control strain.

In Fig. 10, shows that the control of antibacterial activity against $L$. plantum of B.CeM6-7 and Miyagino strains $L$. plantum were presented. It was indicated that, at different timing ( $0 \mathrm{~h}$ to $25 \mathrm{~h}), B$. CeM6-7 had enough ability to fight against MRS broth contained $L$. plantum compared to strain Miyagino. B. CeM6-7 were found to be the most powerful antimicrobial activity at 800 to $860 \mathrm{~min}(12 \mathrm{~h}$ to $13 \mathrm{~h}$ ). At $0 \mathrm{~h}$, all strains were counted to be 0 O.D equally. At $5 \mathrm{~min}$ to $800 \mathrm{~min}(12 \mathrm{~h})$, the B. CeM6-7 was calculated to be 0.02 and 0.06 O.D. Subsequently, $800 \mathrm{~min}(12 \mathrm{~h})$ to 1,500 min $(25 \mathrm{~h})$, the $B$. CeM6-7 was calculated to be 0.06 to 1.80 O.D, which in comparison were less than Miyagino from $300 \mathrm{~min}(5 \mathrm{~h})$ to $1,500 \mathrm{~min}(25 \mathrm{~h})$ which presented at 0.53 to 2.02 O.D. At 1,500 min (25 h), the result has shown so much different turbines of B. CeM6-7 from starting point.

\section{B. Indicator Strain Lb. lactis}

In normally, the bacteriocin produced by three Bacillus strains agents were stable within wide range of $\mathrm{pH}$ values from 4.05 to 4.17 , and nonsignificant different between the $\mathrm{pH}$ values. The effects of heat, $\mathrm{pH}$, nutritional composition and incubation time at $35{ }^{\circ} \mathrm{C}$ and the antibacterial substances were stable within O.D, $650 \mathrm{~nm}(0)$, B. CeM6-7 against. There were exceptions in the case of the Miyagino strain. This strain did not inhibit $L b$. lactis at a temperature of $35^{\circ} \mathrm{C}, 25 \mathrm{~h}$ and it was using as control strain.

The control of antimicrobial activity against $L b$. lactis of three strains B. subtilis and Miyagino after cultured in MRS broth contained against Lb. lactis $(\mathrm{O} . \mathrm{D}=0.1)$ were discussed in Fig. 11. The figure indicated that at $0 \mathrm{~h}$ all of strains were started at 0.00 O.D, and at $180 \mathrm{~min}(3 \mathrm{~h})$ they both were almost had equal O.D (CeM6-7, 0.24 O.D) and (Miyagino, 0.25 O.D. 


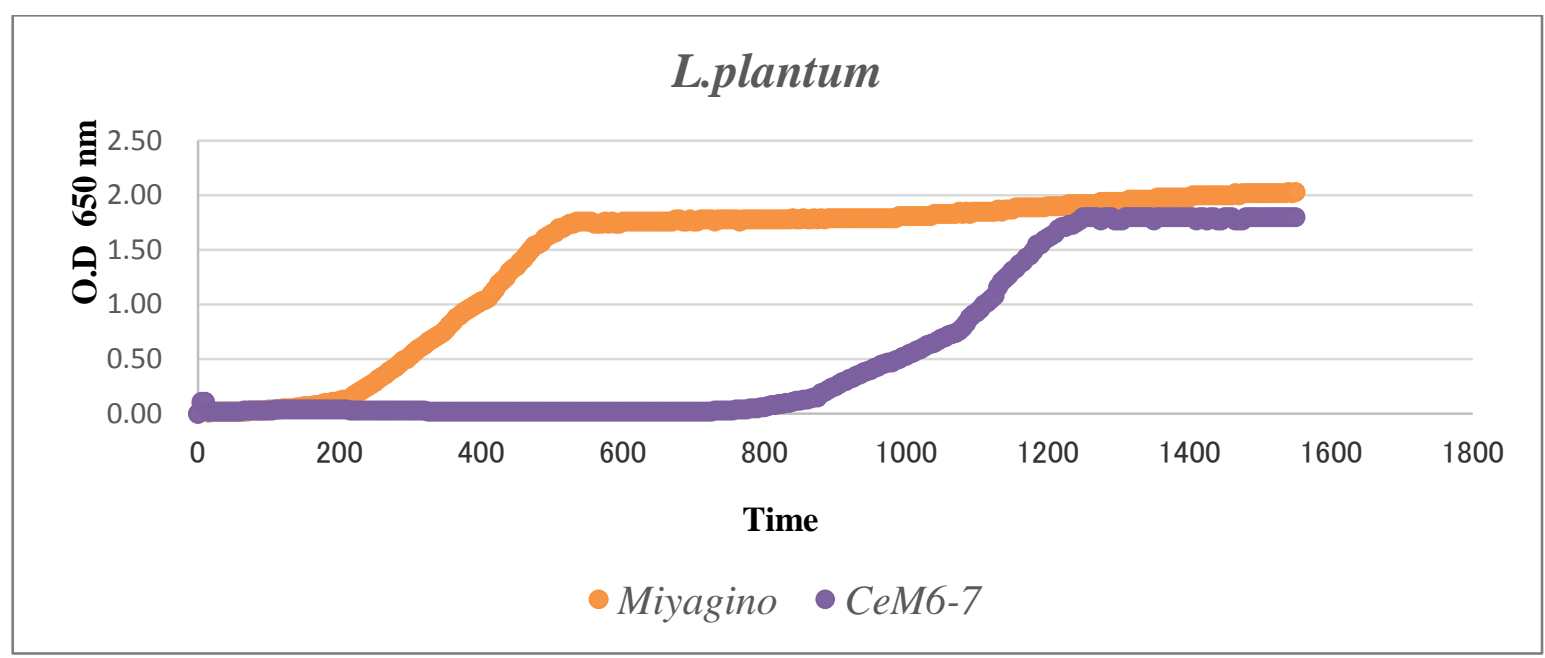

Fig. 10 Effect of bacteriocin produced by B. CeM6-7 strain on the growth of L. plantum compare with Miyagino at different time in MRS broth at $35{ }^{\circ} \mathrm{C}$ for $25 \mathrm{~h}$.

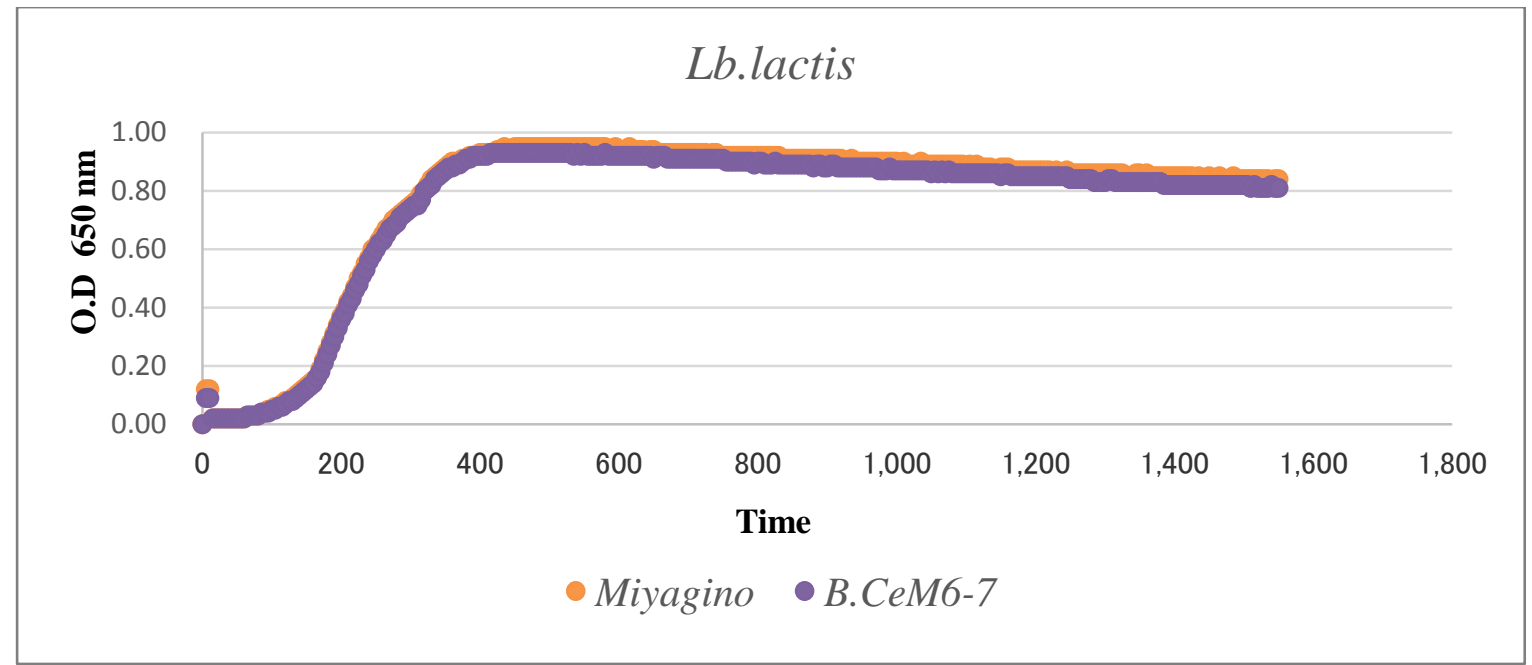

Fig. 11 Effect of bacteriocin produced by B. CeM6-7 strain on the growth of Lb. lactis compare with Miyagino strains at different time in MRS broth at $35{ }^{\circ} \mathrm{C}$ for $25 \mathrm{~h}$.

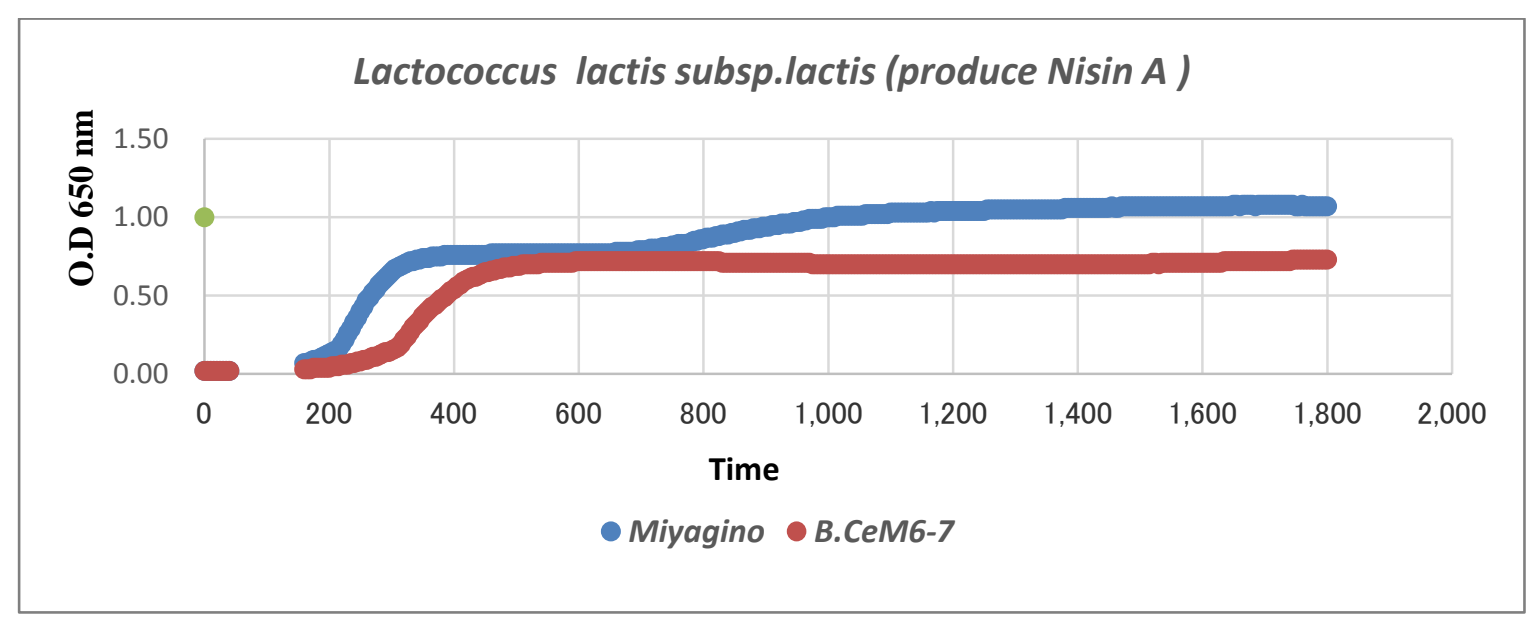

Fig. 12 Effect of bacteriocin produced by B. CeM6-7 strain on the growth of L. lactis subsp. lactis (produce Nisin A) compare with Miyagino at different time in MRS broth at $35^{\circ} \mathrm{C}$ for $30 \mathrm{~h}$. 
Nevertheless, at $600 \mathrm{~min}(10 \mathrm{~h})$ B. CeM6-7 strains were counted to be 0.92 O.D and be able to inactivate MRS broth contained against Lb. lactis, compared with Miyagino (0.94 O.D). From $720 \mathrm{~min}(12 \mathrm{~h})$ to 1,500 min (25 h), B. CeM6-7 strain (0.91-0.82 O.D) shown the most powerful antimicrobial action compared to Miyagino strains. Therefore, B. CeM6-7 strain had higher antibacterial action against $L b$. lactis from $12 \mathrm{~h}$ to $25 \mathrm{~h}$, at $35^{\circ} \mathrm{C}$ unlike Miyagino.

C. Indicator Strain Lactococcuslactis subsp. lactis (produce Nisin A)

The control bacteriocin activity against $L$. lactis subsp. lactis (produce Nisin A) by B.CeM6-7 and Miyagino after cultured in MRS broth contained against Lactococcus lactis subsp. lactis (produce M6-7 Nisin A), O.D = 0.1, $650 \mathrm{~nm}$ at $35^{\circ} \mathrm{C}$ for $30 \mathrm{~h}$. The result shown that the stain B.CeM6-7 produced the strongest antimicrobial activity against MRS broth contained L. lactis subsp. lactis (produce Nisin A) in compared with Miyagino strain.

In Fig. 12, at $0 \mathrm{~h}$, all strains were calculated to be 0.02 O.D equally. In 170 min (2: 50 h), B. CeM6-7 was presented 0.03 O.D which was less than Miyagino that presented at 0.08 O.D. At $600 \mathrm{~min}(10 \mathrm{~h})$ to 825 $\min (14: 15 \mathrm{~h})$ the bacteriocin of B. CeM6-7 increased turbines (Miyagino was counted at 0.77-0.88 O.D and B. CeM6-7 presented at 0.72-0.72 O.D). At $840 \mathrm{~min}$ $(14 \mathrm{~h})$ to $1,530 \mathrm{~min}(25: 50 \mathrm{~h})$ the antibacterial activity produced by B. CeM6-7 was 0.71 and 0.70 O.D respectively less than Miyagino which counted for 0.89 and 1.07 correspondingly. After that, at 1,560 $\min (26 \mathrm{~h})$ to $1,800 \mathrm{~min}(30 \mathrm{~h})$ bacteriocin of $B$. CeM6-7 increase turbines because of the O.D of Miyagino was stable at 1.07 higher than B. CeM6-7 counted for 0.71 and 0.73 O.D. This was indicated that $B$. CeM6-7 shown higher ability to fight against $L$. lactis subsp. lactis (produce Nisin A) compared with Miyagino.

In short, the B. CeM6-7 strain performed very well when treated with $L b$. lactis, especially for MRS broth contained against $L b$. lactis, and were the most powerful to fight against MRS broth contained against L. planum and L. lactis subsp. lactis (produce Nisin A), but it was somewhat higher antimicrobial activity compare to Miyagino to fight against Lb. lactis, though the action is limited. This result was aligned with existing researches stated that, the effect of different $\mathrm{pH}$ on the antimicrobial potentials of the Lactobacillus strains indicates highest inhibitory activities between $\mathrm{pH} 5.5$ to $\mathrm{pH} 7.5$ and the survival rates of the pathogenic indicator bacteria in the fermented food sources were between 8 and 14 days [6].

Applying bacteriocin to control the growth of Gram positive pathogenic or spoilage bacteria of Cambodian strain CeM6-7 indicated that Cambodian strain has similar strength with Miyagino strains (considered to be the strongest one of Gram positive and Lactic acid groups) since it actively produced bateriocin fighting against all three indicator strains of Gram positive and Lactic acid groups from $0-30 \mathrm{~h}$ and $0-25 \mathrm{~h}$ incubation times. Thus, this property of bacteriocins produced by B. CeM6-7 strain can be used as additive in food processing industries to avoid food spoilage even in $35{ }^{\circ} \mathrm{C}$ temperatures and longer time. Many researches on Bacillus bacteriocins are becoming more intensive and important due to their inhibition activity, which may include Gram-negative bacteria in addition to Gram-positive species, some of which are known to be pathogenic to humans and animal [19].

\section{Conclusion}

In this work, we demonstrated the diversity of $B$. subtilis in SIENG, a Cambodian's traditional fermented after culturing in MRS soybean food. 119 samples of Bacillus strains were isolated and there were found only 15 of Bacillus strains that have ability to fight against the indicator microorganisms Lactobacillus plantum ATCC 8014 by agar well diffusion assay. Furthermore, among 15 samples, only one stain (Bacillus CeM6-7) has shown a great active zone against Lactobacillus plantum ATCC 8014. 
Additional finding, Bacillus CeM6-7 strain could tolerate with heat up to $20 \mathrm{~h}$ at $30{ }^{\circ} \mathrm{C}$ temperature and $16 \mathrm{~h}$ at $37{ }^{\circ} \mathrm{C}$. Besides, bacteriocin produced by Bacillus CeM6-7 strain has more ability to suppress all the indicators starts from 20 hours compared with Miyagino stains. Further, it has strength compare with Miyagino originated in Japan, but it has a special unique ability to fight against indicator strain $S A$ at a very significant level.

Moreover, Bacillus CeM6-7 strain performed very well when treated with Gram positive group, against $S$. aureus and Lactic acid groups, against Lactobacillus plantum at a very extensive level. Bacillus CeM6-7 strain has higher strength unlike Japanese strains (Miyagino), since it actively produced bateriocin fighting against all three indicator strains of Gram positive and Lactic acid groups from $0-30 \mathrm{~h}$ and 0-25 $\mathrm{h}$ incubation times.

So, Bacillus CeM6-7 strain can be used as a biological control agent in fermented soybean products to exclude growth of pathogenic or spoilage bacteria during manufacturing without inhibiting the fermentation of Bacillus spp. and may have further uses in the food, agricultural, and pharmaceutical industries.

\section{Acknowledgements}

The authors would like to express our sincere thanks and highly gratitude to this research work supported by Kirin Holdings Co., Ltd. (formerly Kirin Brewery Co., Ltd.), Tokyo, during UNU-Kirin Fellowship Programme at National Food Research Institute, Tsukuba, Japan in 2015-2016.

\section{References}

[1] MAFF. 2013. Annual Report of Ministry of Agriculture, Forestry and Fishery, of the Year 2013-2014 and direction 2014-2015. page 22.

[2] Inatsu, Y., Nakamura, N., Yuriko, Y., Fushimi, T., Watanasiritum, L., and Kawamoto, S. 2006. "Characterization of Bacillus Subtilis Strains in Thua Nao, a Traditional Fermented Soybean Food in Northern Thailand." Letters in Applied Microbiology 43 (3):
237-42.

[3] van Dijl, J. M., and Hecker, M. 2013. "Bacillus Subtilis: From Soil Bacterium to Super-Secreting Cell Factory." Microbial Cell Factories 12 (1): 1-6.

[4] Inatsu, Y., Hosotani, Y., Ananchaipattana, C., Hoque, M. M., and Thong, K. 2012. "Distribution of Bacteriocin Producing Bacillus Subtilis Strains Effective for Controlling Pathogenic/Spoilage Gram-Positive Bacteria in Asian Countries." 477-1017.

[5] Xie, J.-H., Zhang, R.-J., Shang, Ch.-J., and Guo, Y.-Q. 2009. "Isolation and Characterization of a Bacteriocin Produced by an Isolated Bacillus Subtilis LFB112 that Exhibits Antimicrobial Activity against Domestic Animal Pathogens." African Journal of Biotechnology 8 (20): 5611-9.

[6] Adenike, A. O., Mopelola, A., and Adeleye, J. 2007. "In Vitro Antimicrobial Characteristics of Bacteriocin Producing Lactobacillus Strains from Nigerian Indigenous Fermented Foods." African Journal of Biotechnology: 445-53.

[7] Ana, A. Z. 2012. "Antimicrobial Activities of Lactic Acid Bacteria Strains Isolated from Nile Tilapia Intestine (Oreochromisniloticus)." Journal of Biology and Life Science: 164-71.

[8] Askoul, I., Gorrah, S. A., and Al-Amir, L. 2014. "Isolation and Characterization of Bacteriocin Producing Lactic Acid Bacteria from Some Syrian Fermented Foods." International Journal of ChemTech Research, 6, No.4: 2507-20.

[9] Noordiana, N., Fatimah, A. B., and Mun, A. S. 2013. "Antibacterial Agents Produced by Lactic Acid Bacteria Isolated from Threadfin Salmon and Grass Shrimp.' International Food Research Journal 20 (1): 117-24.

[10] Pedersen, P. B., Bjrnvad, M. E., Rasmussen, M. D., and Petersen, J. N. 2002. "Cytotoxic Potential of Industrial Strains of Bacillus Sp." Regulatory Toxicology \& Pharmacology 36 (2): 155-61.

[11] Bhaskar, N., Sudeepa, E. S., Rashmi, H. N., and Tamil Selvi, A. 2007. "Partial Purification and Characterization of Protease of Bacillus Proteolyticus CFR3001 Isolated from Fish Processing Waste and Its Antibacterial Activities." ScienceDirect, Bioresource Technology (98): 2758-64.

[12] Kabore, D., Nielsen, D. S., Sawadogo-Lingani, H., Diawara, B., Dicko, M. H., Jakobsen, M., and Thorsen, L. 2013. "Inhibition of Bacillus Cereus Growth by Bacteriocin Producing Bacillus Subtilis Isolated from Fermented Baobab Seeds (Maari) Is Substrate Dependent.' International Journal of Food Microbiology (162): 114-9.

[13] Chettri, R., and Tamang, J. P. 2015. "Bacillus Species Isolated from Tungrymbai and Bekang, Naturally Fermented Soybean Foods of India." International 
Journal of Food Microbiology 197: 72-6.

[14] Eom, J. S., Lee, S. Y., and Choi, H. S. 2014. "Bacillus Subtilis HJ18-4 from Traditional Fermented Soybean Food Inhibits Bacillus Cereus Growth and Toxin-Related Genes." Journal of Food Science (79): 2279-2287.

[15] Askoul, I., Gorrah, S. A., and Al-Amir, L. 2014. "Isolation and Characterization of Bacteriocin Producing Lactic Acid Bacteria from Some Syrian Fermented Foods." International Journal of ChemTech Research, 6, No.4: 2507-20.

[16] Efendi, Y., and Yusra. 2014. "Bacillus Subtilis Strain VITNJ1 Potential Probiotic Bacteria in the Gut of Tilapia (Oreochromis Niloticus) Are Cultured in Floating Net, Maninjau Lake, West Sumatra." Pakistan Journal of Nutrition 13 (12): 710-5.
[17] Khochamit, N., Siripornadulsil, S., Sukon, P., and Siripornadulsil, W. 2014. "Antibacterial Activity and Genotypic-Phenotypic Characteristics of Bacteriocin Producing Bacillus Subtilis KKU213: MICRES 25708." ScienceDirect, Journal, Microbiological Research (170): 36-50.

[18] Wang, T., Liang, Y.-F., Wu, M.-B., Chen, Zh.-J., Lin, J.-P., and Yang, L.-R. 2015. "Natural Products from Bacillus Subtilis with Antimicrobial Properties." Chinese J Chem Eng (23): 744-54.

[19] Abriouel, H., Franz, C. M. A. P., Omar, N. B., and Galvez, A. 2010. "Diversity and Applications of Bacillus Bacteriocins." Fems Microbiology Reviews 35 (1): 201-32. 